Review Article

\title{
Building Information Modeling (BIM) for Structural Engineering: A Bibliometric Analysis of the Literature
}

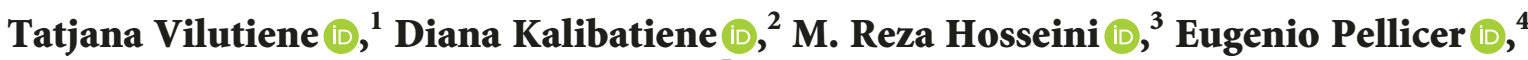 \\ and Edmundas Kazimieras Zavadskas $\mathbb{D i D}^{5}$ \\ ${ }^{1}$ Department of Construction Management and Real Estate, Faculty of Civil Engineering, \\ Vilnius Gediminas Technical University, Vilnius 10223, Lithuania \\ ${ }^{2}$ Department of Information Systems, Faculty of Fundamental Sciences, Vilnius Gediminas Technical University, \\ Vilnius 10223, Lithuania \\ ${ }^{3}$ School of Architecture and Built Environment, Deakin University, Geelong 3220, Australia \\ ${ }^{4}$ School of Civil Engineering, Universitat Politecnica de Valencia, 46022 Valencia, Spain \\ ${ }^{5}$ Institute of Sustainable Construction, Faculty of Civil Engineering, Vilnius Gediminas Technical University, \\ Vilnius 10223, Lithuania \\ Correspondence should be addressed to Tatjana Vilutiene; tatjana.vilutiene@vgtu.lt
}

Received 30 January 2019; Revised 9 June 2019; Accepted 24 June 2019; Published 25 August 2019

Academic Editor: Eul-Bum Lee

Copyright (c) 2019 Tatjana Vilutiene et al. This is an open access article distributed under the Creative Commons Attribution License, which permits unrestricted use, distribution, and reproduction in any medium, provided the original work is properly cited.

Building information modeling (BIM) is transforming the way of work across the architecture, engineering, and construction (AEC) industry, where BIM offers vast opportunities for improving performance. BIM is therefore an area of great interest across the AEC industry in general and for the structural engineering field in particular. This paper is aimed at providing a broad picture of published papers that relate BIM with structural engineering. This overview will enhance understanding of the state of the research work on this subject, drawing upon bibliometric analysis of 369 papers. Findings provide an updated picture of how nowavailable studies that link BIM developments and applications in structural engineering are distributed chronologically, across journals, authors, countries, and institutions. Detailed analyses of citation networks present the cooccurrence map of keywords, citation patterns of journals and articles, the most cited journals, and the top 15 most cited articles on BIM in the area of structural engineering. Discussions demonstrate that research on BIM applications for structural engineering has been constantly growing with a sudden increase after 2014. This study reveals that research attempts on this area have been dominated by exploring generic issues of BIM like information management; however, technical issues of structural engineering, to be resolved through BIM capabilities, have remained overlooked. Moreover, the research work in this area is found to be conducted largely in isolation, comprising disjointed and fragmented research studies. Gaps and important areas for future research include modeling of structural components, automation of the assembly sequence, planning and optimization of off-site construction, and dynamic structural health monitoring.

\section{Introduction}

Building information modeling (BIM) is becoming increasingly popular in the architecture, engineering, and construction (AEC) sector [1-3]; research shows that BIM has the potential to make changes to the way the AEC industry operates $[4,5]$. Analyzing the feedback on the benefits associated with the use of BIM on projects is still a matter of investigation [6]. There is however evidence in the literature to acknowledge the advantages of BIM for various areas and disciplines across the AEC supply chain [7, 8]; BIM incorporates software and information processing procedures for designing, documenting, visualizing, and reporting on buildings and other facilities in integration with policies, standards, regulations, etc. [2]. It helps AEC specialists in visualizing a future building in a virtual environment, planning the forthcoming construction processes, and identifying any potential design, construction, or operational 
issues [1]. Such benefits can add value to the practices of all the disciplines involved, including that of civil engineering, in general, and structural engineering, in particular [9-12].

There have been some in-depth reviews on BIM in general $[9,13-15]$ and studies that have dealt with specific fields like transportation infrastructure, heritage buildings [16], civil infrastructure maintenance [17], collaborative management [18-20], health and safety [21-23], contractors [10], and academics aspects $[24,25]$. Research on the integration of BIM within civil engineering is still in its infancy [9]. Few researchers have focused on civil engineering in particular [26]. Within the civil engineering field, a review run on the BIM literature reveals that some publications like that of Hunt [27] and Bartley [12] have promoted the benefits of BIM for structural engineers. No scholarly work is found with a focus on analyzing the now-available literature on the applications of BIM for structural engineering. Synthesizing the existing literature to raise awareness of the state of affairs of research and spot the gaps to be addressed by future studies is, however, an essential step in advancing the body of knowledge of any field of the study [9, 23]. Various types of review studies can be carried out to address this gap. Despite the undoubted value, an in-depth critical review of the content of existing studies can be prone to subjectivity and is restricted because of their incapability in producing a replicable broad picture of the field [28, 29]. As asserted by Markoulli et al. [30], manual reviews provide a picture of the "trees" but fail in offering a broad overview of the "forest." Since this paper is aimed at providing a broad picture of published academic papers that relate BIM with structural engineering, authors have not applied the content analysis technique for all papers in search results but have analyzed the content of the papers qualitatively.

With the above in mind, this study is targeted at conducting a scientific literature review through a bibliometric analysis of BIM papers related to structural engineering published between 2003 and 2018 (both included). This review, as well as the subsequent analysis, is focused only on scientific journal papers (included in the Scopus database); trade journals and professional magazines are not included here. Detailed analysis of the papers presents the coauthorship networks, the cooccurrence map of keywords, the citation network of journals, the citation network of articles, the list of the most cited journals, and the top 15 most cited articles on BIM in the area of structural engineering. It is deemed that this study contributes to the field in raising awareness of the following:

(1) The knowledge composition of BIM in structural engineering in the analyzed 16-year period

(2) Most recent studies and trends of applying the BIM methodology in structural engineering

(3) Dominant research topics on BIM-related applications in structural engineering

(4) Identifying gaps and defining future areas of research on the topic

The remainder of this paper is structured as follows: Section 2 provides a background on potential advantages and benefits of BIM for structural engineers. Section 3 provides an overview of existing review studies on BIM applications for various disciplines. Section 4 presents the methods used, followed by findings and results in Section 5. The key findings-literature gaps-are discussed and future areas for research are suggested in Section 6 prior to the concluding remarks in Section 7. This paper concludes with communicating the clear message of this study from a broad perspective.

\section{BIM for Structural Engineers}

Structural engineering comprises a wide range of skills and competencies that apply to all project types. This includes projects that entail minor slope strengthening, as well as large-sized structures of tall buildings [12, 31]. Structural engineers can create complex structural systems and are responsible for finding solutions for the efficient use of structural elements and materials in order to make a building and its systems safe, sustainable, and durable [32]. Usually, structural designs must be integrated with the outputs generated by other disciplines like architects and engineers of different building services $[33,34]$. Other roles and responsibilities of structural engineers include supervising construction activities on-site and maintaining communication with manufacturers and suppliers to address production problems [35]. The complexity of the tasks, the required combination of many different competencies, and the abundance of different communication channels necessitate a reliable data exchange platform $[19,36]$. That is, maintaining the quality of the final product requires tools that enable structural engineers to check the parameters of the system under development and verify the reliability of the information transmitted [25]. One available solution that provides all such capabilities is BIM $[9,12]$.

$\mathrm{BIM}$ models are $3 \mathrm{D}$ geometric encoded, in diverse proprietary formats with the potential to add time (4D) and cost data (5D) attached to them [37]. That is, the core concept of BIM relies on providing object-oriented digital representations of buildings in the form of data-rich models and enabling simulation and analysis of these models for design/construction/operation purposes [38]. Most vendors offer BIM software that incorporates the three required capabilities needed for structural engineering: geometry, material properties, and loading conditions for an analysis. These all can be derived directly from a BIM model, stored, edited, and applied by such BIM software. For example, Autodesk Revit can supplement the physical representation of the objects commonly used by structural engineers, and Tekla Structures allows users to specify the location of connection nodes on its objects and degrees of freedom and also has objects to model structural loads and load cases (see Sacks et al. [38] for details).

Moreover, using BIM in structural engineering can reduce the number of request for information (RFI) items from contractors and makes possible the visualization of design for clients and other stakeholders [39]. BIM can also provide all the stakeholders with the opportunity to explore various readily available alternatives and design scenarios $[40,41]$. 
The digital models produced by structural engineers can be coupled with downstream activities, for manufacturing and assembly of structural elements as well as identifying coordination problems between structural elements and those of other disciplines [1, 34]. BIM can be a part of an effective solution for structural engineers in monitoring the health and life cycle performance of structural elements, seismic retrofitting optimization [42, 43], and risk assessment of structures [44]. Other applications of BIM for structural engineering include increasing its efficiency in modeling complex geological structures, generating shop drawings, and designing temporary elements and formwork $[43,45]$.

With the above in mind, structural design/analysis must be treated as one of the main areas of application for BIM, a point argued by Hosseini et al. [9]. This further justified the need for conducting this study.

\section{Previous Discipline-Based Review Studies}

Structural engineering is a subset of civil engineering [46]. Available studies have targeted different issues of civil engineering projects concerning BIM: developments of BIM implementations [13]; communication modes [47]; information management frameworks [10]; refurbishment of historic buildings using BIM $[16,48]$; implementation of BIM to existing buildings [49]; sustainable buildings $[8,50]$; BIM adoption in different civil infrastructure facilities [26]; roles and responsibilities of BIM practitioners [51]; conceptualization of a BIM-based facilities management framework [52, 53]; visualization technologies in safety management [21, 23]; data classifications [54]; BIM knowledge mappings [14]; BIM research categories [55]; application of laser scan technology [56]; challenges facing the facilities management sector $[52,57,58]$; application of semantic web technologies; issues and recommendations for BIM and life cycle assessment tools [59]; BIM and GIS [60]; green BIM [61]; collaboration in BIM networks [19]; transportation infrastructure; road infrastructure [62]; highway maintenance [17]; role of BIM in generating big data [37], etc. These studies have added much value to the BIM literature and have explored a wide range of fields associated with civil engineering. Civil engineering is however a broad field, with many subsets, as argued by Kosky et al. [46]. A list of major review studies that refer to BIM for civil engineering is tabulated in Table 1. As illustrated in Table 1, no review study has focused on BIM applications for structural engineering purposes. In fact, as argued by Hosseini et al. [9], BIM for structural engineering has remained an overlooked area in the extant literature, compared against other applications of BIM.

\section{Research Methods}

The research design for reviewing papers on BIM in structural engineering is displayed in Figure 1. The procedure begins with a brief review of published papers on BIM in Scopus, proceeds to a detailed review of the refined dataset of publications, and concludes by analyzing the data.

This research process, as illustrated in Figure 1, comprises the following steps:

(1) Defining Research Questions. Research questions are defined in this step. The scope of the research questions depends on the type of the study. Therefore, according to Merschbrock and Munkvold [68] and Arksey and O'Malley [69], this study is a scoping study and designed to examine the available journal articles and to determine the range of spreading and usage of BIM and new trends of BIM developments in structural engineering. The research question is formulated as "What is known from the existing literature about the applications of BIM methodology and tools in structural engineering?"

(2) Defining the List of Search Sources. The Scopus (https://www.scopus.com) database was chosen, given that compared against similar databases like Web of Science (WoS), Scopus covers a wider range of sources and is quicker in indexing them, and therefore, it is treated as the preferred database for bibliometric purposes.

(3) Defining Search Query Based on Keywords. Searching keywords and their meaningful combinations are defined as the following search query, using keywords: (BIM AND "Building Information Model*” AND struct*).

Other terms, like "digital model" and "3D modelling," can also be used in the search. However, adding such terms increases the number of results but does not make it more specific. The term "BIM" was omitted, given that as recommended by previous bibliometric studies on the BIM literature [9], including BIM can result in adding research items from nonconstruction contexts like chemistry and economics and increase the likelihood of unrelated studies being added to the dataset.

Therefore, they were excluded from the search. Moreover, using the special character* in the query results in finding different variations of the same concept; for example, usage of "model*" allows to extend the search by adding different variations, like "models," "modelling," and "modeling." This is also the case for "struct*"; that is, it finds "structure," "structural," etc.

(4) Searching. The searching process is performed according to the query defined in step 3, and the preliminary results are presented in Figure 2.

(5) Assessing Quality of Results. Quality of results is assessed here. According to Kitchenham et al. [70], there is no commonly agreed definition of "quality." Therefore, quality issues presented by Zhang et al. [71] were the basis for consideration.

(6) Bibliometric Analysis of Search Results. The bibliometric analysis technique is used as the primary analysis method, with the reason being this 
TABLE 1: Summary of major review studies on BIM for civil engineering.

\begin{tabular}{|c|c|c|c|c|c|}
\hline Source & $\begin{array}{l}\text { Review } \\
\text { period in } \\
\text { years }\end{array}$ & $\begin{array}{c}\text { Number of analyzed } \\
\text { articles }\end{array}$ & $\begin{array}{l}\text { Source of articles } \\
\text { (databases) }\end{array}$ & Focus & Key findings \\
\hline Abdirad [13] & $2007-2014$ & 97 (selected out of 322 ) & $\begin{array}{l}\text { ASCE, Elsevier, Taylor \& } \\
\text { Francis, Emerald, } \\
\text { and ITcon }\end{array}$ & $\begin{array}{l}\text { BIM implementation } \\
\text { assessment }\end{array}$ & $\begin{array}{l}\text { Developments of BIM } \\
\text { implementations; metric- } \\
\text { based BIM assessment; } \\
\text { gaps and limitations }\end{array}$ \\
\hline $\begin{array}{l}\text { Bradley et al. } \\
{[10]}\end{array}$ & $2000-2015$ & 259 & $\begin{array}{c}\text { Scopus, Engineering } \\
\text { Village, ScienceDirect, } \\
\text { WoS }\end{array}$ & BIM for infrastructure & $\begin{array}{l}4 \text { research gaps in } \\
\text { infrastructure and BIM; } \\
\text { an information } \\
\text { management framework }\end{array}$ \\
\hline $\begin{array}{l}\text { Bruno et al. } \\
{[48]}\end{array}$ & $2007-2017$ & $\begin{array}{l}\text { 120, } 86 \text { of them with } \\
\text { international impact, } \\
\text { and } 1 \text { project }\end{array}$ & - & Historic BIM & $\begin{array}{l}\text { Gaps in historic BIM; } \\
\text { methodology for } \\
\text { diagnosis of historic } \\
\text { buildings using BIM }\end{array}$ \\
\hline $\begin{array}{l}\text { Cheng et al. } \\
{[26]}\end{array}$ & $2002-2014$ & $\begin{array}{c}171 \text { case studies and } 62 \\
\text { articles }\end{array}$ & - & $\begin{array}{l}\text { BIM for civil } \\
\text { infrastructure }\end{array}$ & $\begin{array}{l}\text { Current practices of BIM } \\
\text { adoption in different civil } \\
\text { infrastructure facilities; } \\
\text { research gaps and } \\
\text { recommendations; } \\
\text { evaluation framework }\end{array}$ \\
\hline $\begin{array}{l}\text { Davies et al. } \\
{[51]}\end{array}$ & $2007-2016$ & $\begin{array}{l}36 \text { articles and BIM } \\
\text { guides }\end{array}$ & - & $\begin{array}{l}\text { Roles and } \\
\text { responsibilities of BIM } \\
\text { specialists }\end{array}$ & $\begin{array}{c}\text { Definition of roles and } \\
\text { responsibilities of BIM } \\
\text { practitioners }\end{array}$ \\
\hline $\begin{array}{l}\text { Edirisinghe } \\
\text { et al. [52] }\end{array}$ & 1996-2016 & 46 (selected out of 207) & - & $\mathrm{BIM}$ in FM & $\begin{array}{l}\text { Conceptualization of a } \\
\text { BIM-based FM } \\
\text { framework; determining } \\
\text { the path of future research }\end{array}$ \\
\hline $\begin{array}{l}\text { Guo et al. } \\
{[21]}\end{array}$ & $2000-2015$ & 78 & $\begin{array}{l}\text { WoS and ASCE } \\
\text { Library databases }\end{array}$ & $\begin{array}{l}\text { The use of } \\
\text { visualization technology }\end{array}$ & $\begin{array}{c}\text { Usage of visualization } \\
\text { technologies in safety } \\
\text { management }\end{array}$ \\
\hline $\begin{array}{l}\text { Kylili and } \\
\text { Fokaides [63] }\end{array}$ & $2005-2016$ & $\begin{array}{c}\text { Actual European policies } \\
\text { and legislation }\end{array}$ & $\begin{array}{c}\text { European policies and } \\
\text { legislation }\end{array}$ & $\begin{array}{l}\text { Existing European } \\
\text { policies and legislation for } \\
\text { the built environment and } \\
\text { the construction materials }\end{array}$ & $\begin{array}{l}\text { Future trends in } \\
\text { construction }\end{array}$ \\
\hline $\begin{array}{l}\text { Laakso and } \\
\text { Nyman }[54]\end{array}$ & $1997-2007$ & $\begin{array}{l}\text { The first } 11 \text { years of } \\
\text { research on } \\
\text { standard } 938\end{array}$ & - & $\begin{array}{c}\text { Research and } \\
\text { BIM standardization }\end{array}$ & Classification of data \\
\hline Li et al. [14] & 2004-2015 & & WoS & BIM knowledge map & $\begin{array}{l}60 \text { key research areas } \\
10 \text { key research clusters }\end{array}$ \\
\hline $\begin{array}{l}\text { Lopez et al. } \\
{[64]}\end{array}$ & - & $\begin{array}{l}\text { BIM software websites, } \\
\text { articles, brochures, and } \\
\text { videos }\end{array}$ & - & $\begin{array}{c}\text { The readiness and } \\
\text { development of } 4 \mathrm{D} \text { BIM }\end{array}$ & $\begin{array}{l}\text { A BIM knowledge map; a } \\
\text { review of different issues } \\
\text { concerning the usability of } \\
\text { 4D BIM; matrices for } \\
\text { decision-making } \\
\text { according to investment } \\
\text { in BIM software }\end{array}$ \\
\hline $\begin{array}{l}\text { Olawumi } \\
\text { et al. [55] }\end{array}$ & - & 445 & - & BIM research categories & $\begin{array}{l}\text { BIM research categories in } \\
\text { the project sectors; a } \\
\text { visualization of the } \\
\text { structure of the BIM } \\
\text { literature }\end{array}$ \\
\hline $\begin{array}{l}\text { Pärn and } \\
\text { Edwards [56] }\end{array}$ & $1970-2015$ & - & - & $\begin{array}{c}\text { Laser scanning, 3D } \\
\text { modeling devices, modes } \\
\text { of delivery, and } \\
\text { applications within } \\
\text { AECO }\end{array}$ & $\begin{array}{l}\text { Hierarchy of laser scan } \\
\text { devices; analysis of 3D } \\
\text { terrestrial laser scan } \\
\text { technology applications }\end{array}$ \\
\hline $\begin{array}{l}\text { Pärn et al. } \\
\text { [57] }\end{array}$ & 2004-2015 & - & - & $\begin{array}{c}\text { BIM for asset } \\
\text { management within } \\
\text { the AECO sector }\end{array}$ & $\begin{array}{c}\text { Challenges facing the FM } \\
\text { sector }\end{array}$ \\
\hline
\end{tabular}


TABLE 1: Continued.

\begin{tabular}{|c|c|c|c|c|c|}
\hline Source & $\begin{array}{l}\text { Review } \\
\text { period in } \\
\text { years }\end{array}$ & $\begin{array}{c}\text { Number of analyzed } \\
\text { articles }\end{array}$ & $\begin{array}{l}\text { Source of articles } \\
\text { (databases) }\end{array}$ & Focus & Key findings \\
\hline $\begin{array}{l}\text { Santos et al. } \\
\text { [65] }\end{array}$ & 2005-2015 & 381 & - & BIM & $\begin{array}{l}\text { New emerging areas in } \\
\text { BIM research; topics } \\
\text { related to the } \\
\text { development of BIM tools }\end{array}$ \\
\hline $\begin{array}{l}\text { Soust- } \\
\text { Verdaguer } \\
\text { et al. [59] }\end{array}$ & - & - & - & $\begin{array}{l}\text { LCA method for buildings } \\
\text { based on BIM }\end{array}$ & $\begin{array}{l}\text { Issues and } \\
\text { recommendations for } \\
\text { BIM and LCA tools }\end{array}$ \\
\hline Zhao [15] & $2005-2016$ & 614 & WoS & BIM & $\begin{array}{l}\text { The most productive and } \\
\text { cocited authors, countries, } \\
\text { and institutions }\end{array}$ \\
\hline $\begin{array}{l}\text { Oraee et al. } \\
{[19]}\end{array}$ & 2006-2016 & 62 & - & $\begin{array}{c}\text { Collaboration in BIM- } \\
\text { based construction } \\
\text { networks }\end{array}$ & $\begin{array}{l}\text { BIM-enabled projects } \\
\text { have focused on } \\
\text { technology, whilst } \\
\text { project-related and } \\
\text { managerial antecedents } \\
\text { have remained } \\
\text { underresearched }\end{array}$ \\
\hline $\begin{array}{l}\text { Martinez- } \\
\text { Aires et al. } \\
{[22]}\end{array}$ & $1981-2016$ & 76 & WoS and Scopus & $\begin{array}{l}\text { Occupational health and } \\
\text { safety in building } \\
\text { construction }\end{array}$ & $\begin{array}{l}\text { BIM to improve safety in } \\
\text { construction and identify } \\
\text { potential hazards through } \\
\quad 4 \mathrm{D} \text { scheduling }\end{array}$ \\
\hline $\begin{array}{l}\text { Ganbat et al. } \\
\text { [66] }\end{array}$ & 2007-2017 & 526 & WoS & $\begin{array}{l}\text { BIM risk management in } \\
\text { international construction }\end{array}$ & $\begin{array}{l}\text { A framework of current } \\
\text { research field; suggestions } \\
\text { for future research } \\
\text { directions }\end{array}$ \\
\hline Jin et al. [67] & & 276 & Scopus & $\begin{array}{c}\text { Identifying research } \\
\text { trends in the literature on } \\
\text { BIM }\end{array}$ & $\begin{array}{l}\text { A framework leading to } \\
\text { needed research } \\
\text { directions }\end{array}$ \\
\hline
\end{tabular}

Note. - : data not provided.

technique allows for an examination of the existing literature based solely on reported data, in which any potential for author bias is minimized, compared against conventional literature reviews that are prone to bias and subjective judgments [55]. The findings of studies based on bibliometric analysis are hence expected to provide a sound basis for the development of various hypotheses based on the observed trends extracted from published datasets for validation in future studies.

Various researchers, like Li et al. [14], Zhao [15], and Santos et al. [65], have used different science mapping tools, including VOSviewer, BibExcel, CiteSpace, CoPalRed, Sci2, VantagePoint, and Gephi, for analyzing, mapping, and visualization of bibliometric data. A detailed review of visualization tools is not the main aim of this paper, and hence, VOSviewer (http://www.vosviewer.com/) was used as the analysis tool, following the recommendations provided by Hosseini et al. [9]. VOSviewer generates a network from the given bibliographic data, i.e., a set of 369 articles. All networks consist of nodes and links. Nodes present documents (i.e., articles), sources (i.e., journals), authors, organizations, countries, or keywords. Nodes with a higher number of occurrences are bigger. Links present relationships among nodes. Thicker links present closer relationships among nodes. Closely related nodes are combined into clusters using the smart local moving algorithm presented by Waltman and Van Eck [72].

\section{Results}

5.1. Trend of Research. The results obtained from the bibliometric search demonstrate the trend of research on the topic, as illustrated in Figure 2. The number of publications on BIM for structural engineering has raised significantly from 2014 onwards, with two years of delay compared against the sudden increase in BIM research in 2012, as argued by Santos et al. [65]. This increase from 2012 onwards can be attributed to the 2011 mandate of the Government Construction Strategy of the United Kingdom on the use of Level 2 BIM on all public sector projects by 2016 [73]. There is a growing interest (see Figure 2 for the exponential growth of publications), acknowledging the necessity of further research in this area. This also highlights the importance of covering various areas related to this concept as topics for future research, as similarly argued by Hosseini et al. [9]. In fact, construction is composed of a wide range of loosely coupled disciplines [74-76], and the expansion of BIM across the construction supply chain has been sluggish [58]. Therefore, the number of studies on structural engineering and BIM is quite low; compared with the results obtained by 


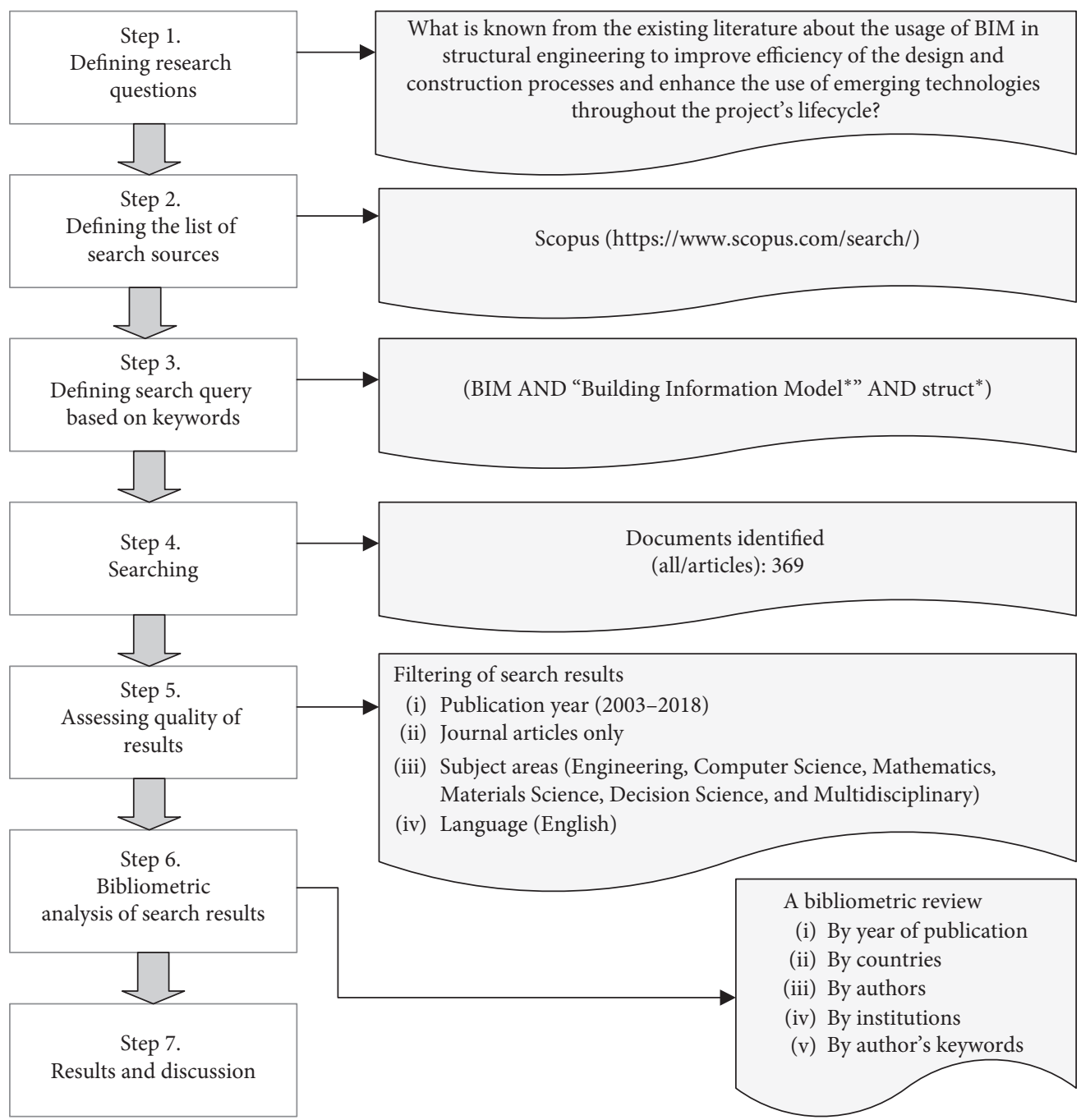

FIGURE 1: Research design for bibliometric analysis of retrieved papers.

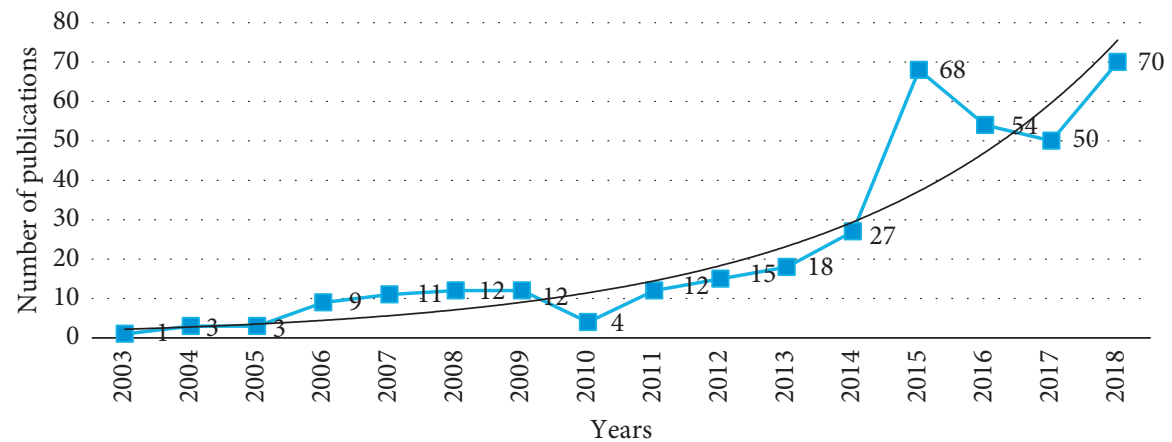

— Expon. (exponential growth of publications)

FIGURE 2: Variations in the number of BIM publications in the area of structural engineering.

Hosseini et al. [9], less than $20 \%$ of studies on BIM referred to structural engineering applications. This acknowledges the claims in the literature about the lack of attention paid to structural engineering in the BIM literature $[9,77,78]$.

\subsection{Coauthorship Networks. Identifying existing research} collaboration networks on a topic has several advantages:
(1) the awareness can facilitate access to funds, and needed, (2) the awareness will result in higher productivity, and (3) the awareness assists investigators to reduce silo-based and isolated research activities with boosting scholarly communications [79]. In Figure 3, a coauthorship network of authors is generated from the core dataset, as a result of which VOSviewer detects 836 authors. In Figure 3, a minimum of three 


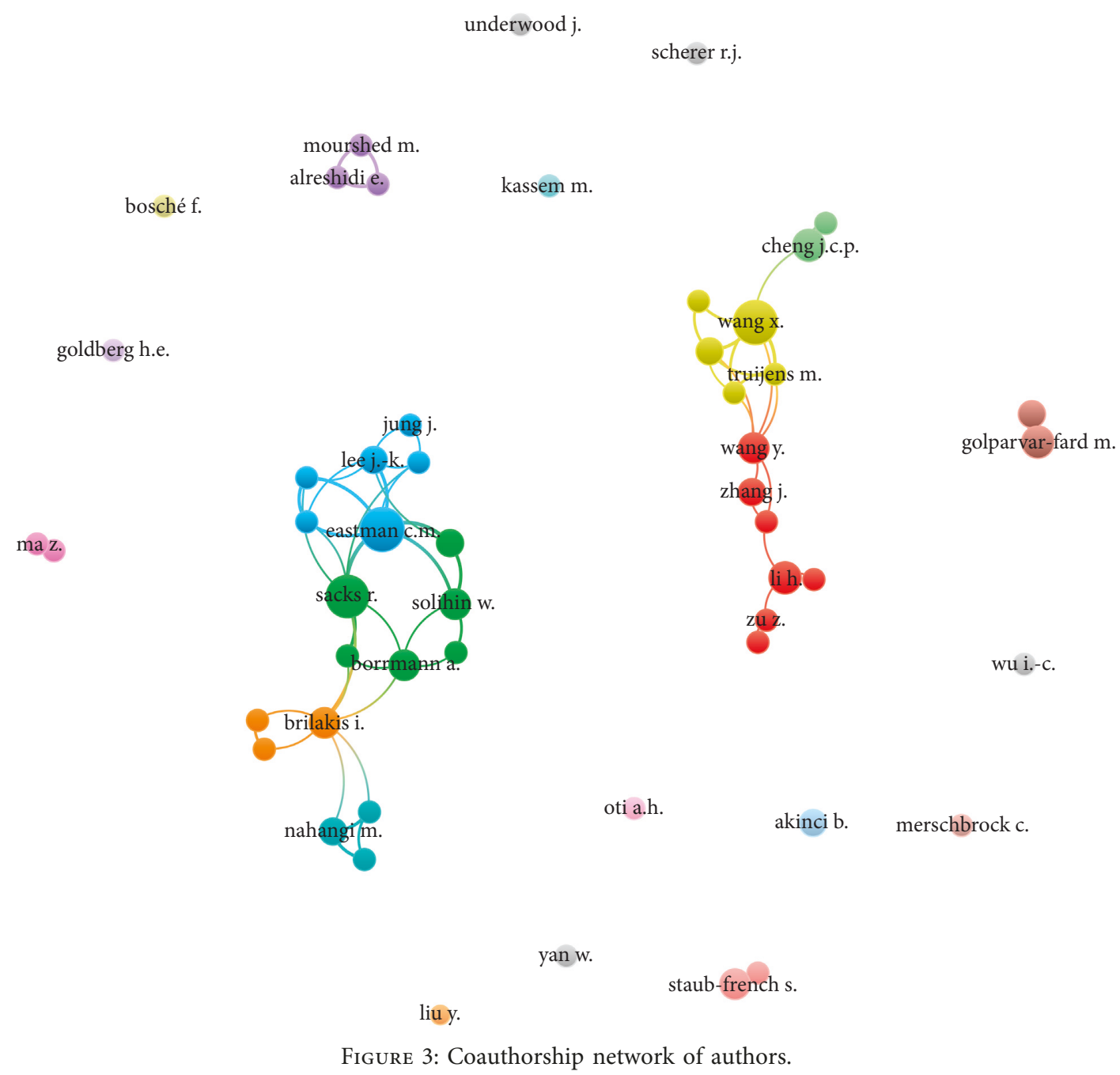

TABLE 2: The most active authors, whose number of articles focusing on BIM for structural engineering exceeds three.

\begin{tabular}{lccc}
\hline Author & Number of articles & \% of articles & Number of citations \\
\hline C. M. Eastman & $\mathbf{1 1}$ & $\mathbf{1 3 . 7 5}$ & $\mathbf{7 0 4}$ \\
R. Sacks & $\mathbf{1 0}$ & $\mathbf{1 2 . 5 0}$ & $\mathbf{4 7 6}$ \\
X. Wang & $\mathbf{1 0}$ & $\mathbf{1 2 . 5 0}$ & $\mathbf{3 9 6}$ \\
M. Golparvar-Fard & 6 & 7.50 & 278 \\
A. Borrmann & 5 & 6.25 & 46 \\
I. Brilakis & 5 & 6.25 & 172 \\
S. Staub-French & 5 & 6.25 & 31 \\
B. Akinci & $\mathbf{4}$ & $\mathbf{5 . 0 0}$ & $\mathbf{3 1 8}$ \\
K. K. Han & 4 & 5.00 & 155 \\
L. Hou & 4 & 5.00 & 93 \\
J.-K. Lee & $\mathbf{4}$ & $\mathbf{5 . 0 0}$ & $\mathbf{2 9 9}$ \\
Y.-C. Lee & 4 & 5.00 & 42 \\
M. Nahangi & 4 & 5.00 & 105 \\
W. Solihin & 4 & 5.00 & 33 \\
Total & 80 & 100 & \\
\hline
\end{tabular}

Bold values depict the most cited authors in the set of leading authors in a group of coauthorship.

documents per author were chosen. After applying VOSviewer algorithms, 52 authors were obtained. Figure 3 depicts eleven collaboration networks of authors in isolated groups and ten single authors disconnected from the network.
Authors with strong relationships and more articles are set as leading authors in a group of coauthorship. The most active authors, having more than three published articles, are presented in Table 2. 
Ranking authors by the number of citations is different from ranking by the number of articles. Citations offer an indication of prominence, as a widely accepted measure for ranking the influence level of authors [80]. Therefore, a network of authors based on their citations was analyzed (see Figure 4). In Figure 4, a minimum of 10 citations of an author were chosen to make the analysis manageable. After applying VOSviewer algorithms, the result of the citation network of 49 authors is obtained. The most cited five authors are as follows: Eastman (704 citations), Sacks (476 citations), Wang (396 citations), Akinci (318 citations), and Lee (299 citations).

In view of the outcomes from Figures 3 and 4, several findings are worth mentioning. First, some large collaboration networks contribute to a major part of research on BIM in structural engineering, in the form of a "linked research enterprise," as termed by Newman [81].

Though presenting a promising picture, this also demonstrates that a major part of research on BIM in structural engineering is dominated by several researchers in a closed circle, calling for more investigation from other authors outside the identified research circle.

Second, a clear intellectual isolation from the mainstream of research on the topic is illustrated, where those who do not belong to the existing clusters form very small and disconnected clusters disjointed from the remaining parts of the network. This calls for more effort to integrate the existing disconnected clusters into one large linked research enterprise, not dominated by few investigators in a closed circle.

A coauthorship network of countries generated from the core dataset presented is illustrated in Figure 5.

A set of 50 countries is identified by VOSviewer (see Figure 5). After applying VOSviewer algorithms, the result of 26 countries is obtained. Finland, India, Norway, Sweden, and Taiwan have no interconnections with other countries; therefore, they are not presented in Figure 5. However, as can be seen in Table 3 , the distribution of countries according to the number of citations differs. Here, the five leading countries are United States (2074 citations), United Kingdom (968 citations), South Korea (941 citations), Australia (656 citations), and China (592 citations), which were also referred by Jin et al. [82], as the current leaders in BIM adoption. This shows that many countries, including European countries (Germany, Italy, France, Netherlands, Spain, and Belgium), have had technological advancements in terms of applying BIM for various civil engineering purposes. That said, research activities in these countries and the level of influence of investigators from these countries in facilitating the integration of structural engineering with BIM have a noticeable gap with those in the five leading countries in the field, as discussed.

Table 4 introduces the top organizations that have published more than five papers. As can be seen, the most active four organizations are the Georgia Institute of Technology (16 articles), Curtin University (14 articles), Tsinghua University (13 articles), and Technion-Israel Institute of Technology (10 articles). This also reiterates the findings as discussed: other than few leading countries, institutions in other countries, even in countries with advanced BIM technology like European countries, have overlooked the importance of conducting research to facilitate and expedite the permeation of BIM-based structural engineering and stand far away from their counterparts in leading countries identified in Figure 4.

5.3. Cooccurrence Network. The cooccurrence analysis is usually performed using keywords, to present the main content of articles and the range of researched areas in any domain of the study [83]; it provides a picture of a domain, main areas of research, and trends of development. The cooccurrence analysis of the keyword network is performed using authors' keywords. VOSviewer creates the keyword network by considering the closeness and strength of existing links. The closeness and strength are calculated from the number of publications, in which both keywords have occurred together [80].

VOSviewer identified 2869 keywords from the initial set of 369 articles. Applying VOSviewer algorithms and limiting the minimum number of occurrences of a term to five times, the result was obtained from 147 keywords. The generated set of keywords must be refined again. That is, VOSviewer is capable of identifying synonyms and words with identical meaning, even with different orthography, like "modelling" and "modeling" and "technology" and "technologies." Moreover, similar keywords, like BIM, and building information model have the largest number of occurrences, given the nature of the topic at hand [9]. Therefore, in order to avoid distortion of the results, the resultant set of keywords was refined to omit such unnecessary items in the list. The refining procedure includes the following steps following the lessons by Hosseini et al. [9]:

(i) Elimination of terms related to BIM and having the same meaning, like "BIM," "building information model," and "building information modelling." The primary search of articles was made according to those terms, and it is natural that these terms will be repeated in each analyzed paper and will have the highest number of occurrences and total link strength calculated by VOSviewer.

(ii) Elimination of generic terms, like "construction industry," "architectural design," and "information theory," since those terms have the highest number of occurrences and total link strength, calculated by VOSviewer, because of searching query specifics in this area.

Moreover, as can be seen from Figure 6, the keyword map is visualized using various colors to show the chronological order of items.

In Figure 6, the most occurred keywords are presented. From Figure 6 and Table 5, the most occurred keywords in three periods are presented next. In the period 2010-2012 (colored in blue), the most popular keywords are "project management," "three dimensional," "productivity," 


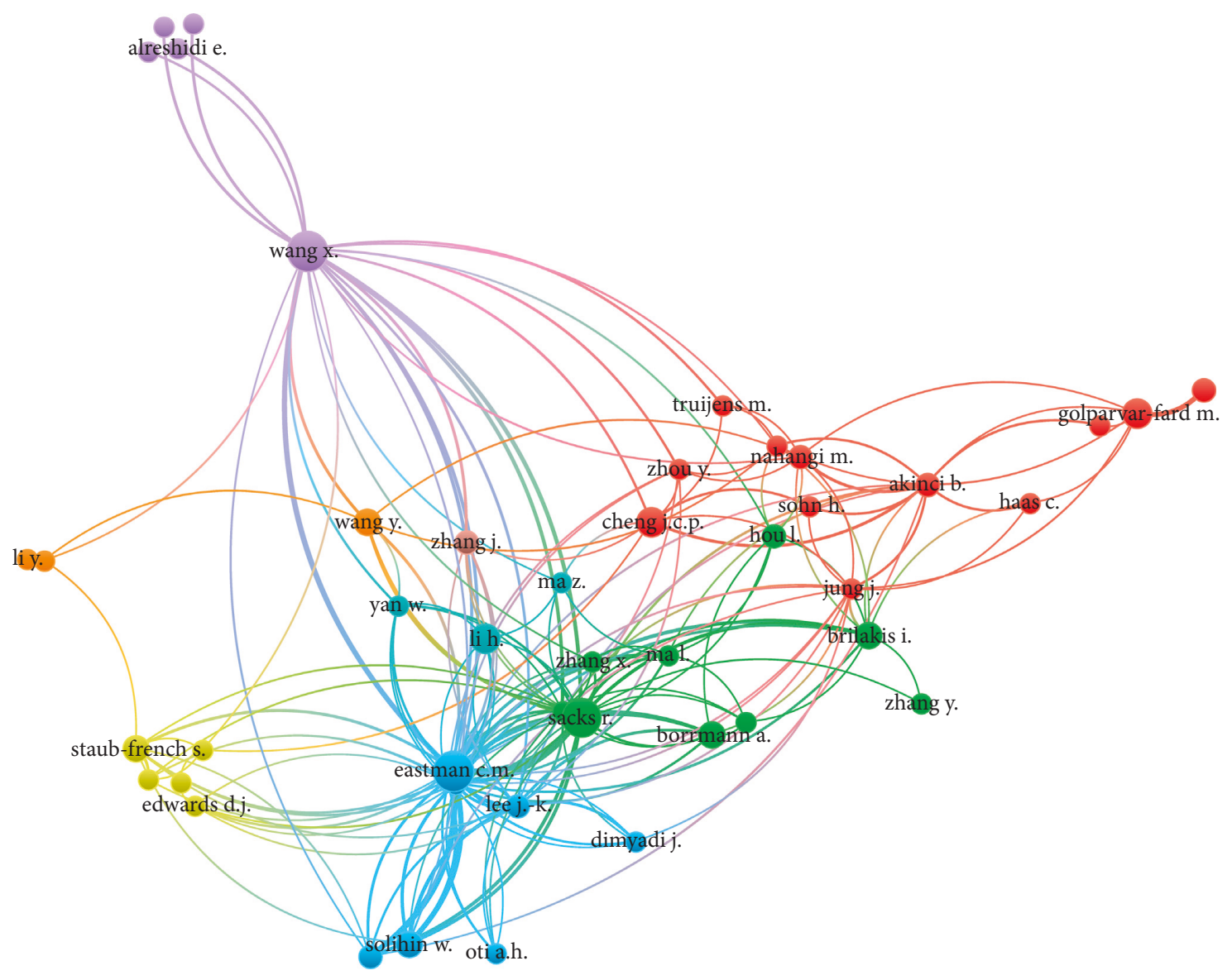

Figure 4: Citation network of authors.

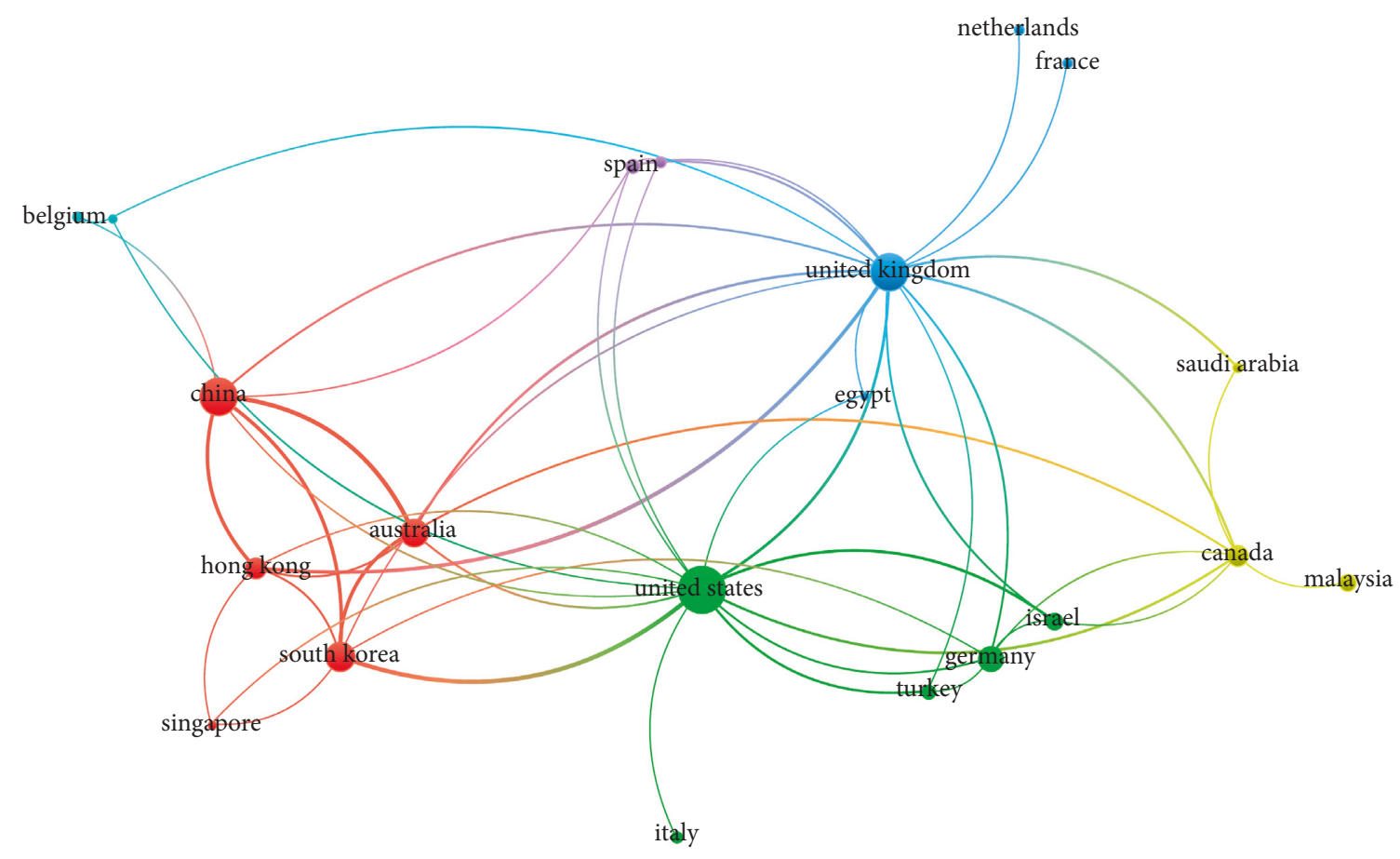

FIGURE 5: Coauthorship network of countries. 
TABle 3: The most active countries, where the number of articles exceeds or equals 5 (Scopus, December 2018).

\begin{tabular}{lccc}
\hline Country & Number of articles & \% of articles & Number of citations \\
\hline United States & $\mathbf{8 7}$ & $\mathbf{2 0}$ & $\mathbf{2 0 7 4}$ \\
United Kingdom & $\mathbf{5 7}$ & $\mathbf{1 3}$ & $\mathbf{9 6 8}$ \\
China & $\mathbf{5 5}$ & $\mathbf{1 3}$ & $\mathbf{5 9 2}$ \\
South Korea & $\mathbf{3 4}$ & $\mathbf{8}$ & $\mathbf{9 4 1}$ \\
Australia & $\mathbf{3 0}$ & $\mathbf{7}$ & $\mathbf{6 5 6}$ \\
Germany & 25 & 6 & 272 \\
Canada & 19 & 4 & 316 \\
Hong Kong & 18 & 4 & 201 \\
Israel & 11 & 3 & 477 \\
Malaysia & 11 & 3 & 34 \\
Taiwan & 9 & 2 & 41 \\
Spain & 8 & 2 & 258 \\
Turkey & 8 & 2 & 231 \\
Ireland & 6 & 1 & 82 \\
Italy & 6 & 1 & 71 \\
Finland & 6 & 1 & 42 \\
India & 6 & 1 & 39 \\
Norway & 5 & 1 & \\
\hline
\end{tabular}

TABLE 4: The most active organizations, whose number of articles exceeds and equals 5.

\begin{tabular}{lc}
\hline Organizations & Number of articles \\
\hline Georgia Institute of Technology (United States) & $\mathbf{1 6}$ \\
Curtin University (Australia) & $\mathbf{1 4}$ \\
Tsinghua University (China) & $\mathbf{1 3}$ \\
Technion-Israel Institute of Technology (Israel) & $\mathbf{1 0}$ \\
University of Salford (United Kingdom) & 9 \\
Hanyang University (South Korea) & 9 \\
Kyung Hee University (South Korea) & 8 \\
Hong Kong University of Science and Technology & $\mathbf{3 . 8 7}$ \\
(Hong Kong) & 8 \\
Hong Kong Polytechnic University (Hong Kong) & 8 \\
Cardiff University (United Kingdom) & 8 \\
University of Illinois at Urbana-Champaign (United & $\mathbf{3 . 4 5}$ \\
States) & 6 \\
University of Waterloo (Canada) & 6 \\
Technical University of Munich (Germany) & 6 \\
Texas A\&M University (United States) & 6 \\
Carnegie Mellon University (United States) & 6 \\
University of Cambridge (United Kingdom) & 6 \\
Pennsylvania State University (United States) & 6 \\
The University of British Columbia (Canada) & 5 \\
Yonsei University (South Korea) & 1.94 \\
University of New South Wales (UNSW) (Australia) & 5 \\
\hline
\end{tabular}

The bold values depict the most active four organizations.

"computer aided design," "database systems," "algorithms," "software design," "virtual reality," "standards," etc. The most occurred keywords in the period from 2013 to 2015 (colored in green) are "information systems," "information management," "industry foundation classes," "life cycle," "interoperability," "decision making," "energy efficiency," "semantics," etc. The most occurred keywords in the period 2016-2018 (colored in yellow) are "simulation," "automation," "data handling," "point cloud," "object detection," "cost benefit analysis," "risk assessment," "efficiency," "model view definition," etc. Arranging the keywords according to the citation score (see "Average citations" column in Table 5) results in generating a slightly different picture. That is, the popularity of terms according to the citation score in the three periods is as follows:

(i) 2010-2012: "in-buildings," "three dimensional," "productivity," "concrete construction," "computer aided design," "database systems," "algorithms," "software design," "virtual reality," etc.

(ii) 2013-2015: "model checking," "AEC," "planning," "scanning," "scheduling," "geometry," "interoperability," "design and construction," "collaboration," "precast concrete," etc. 


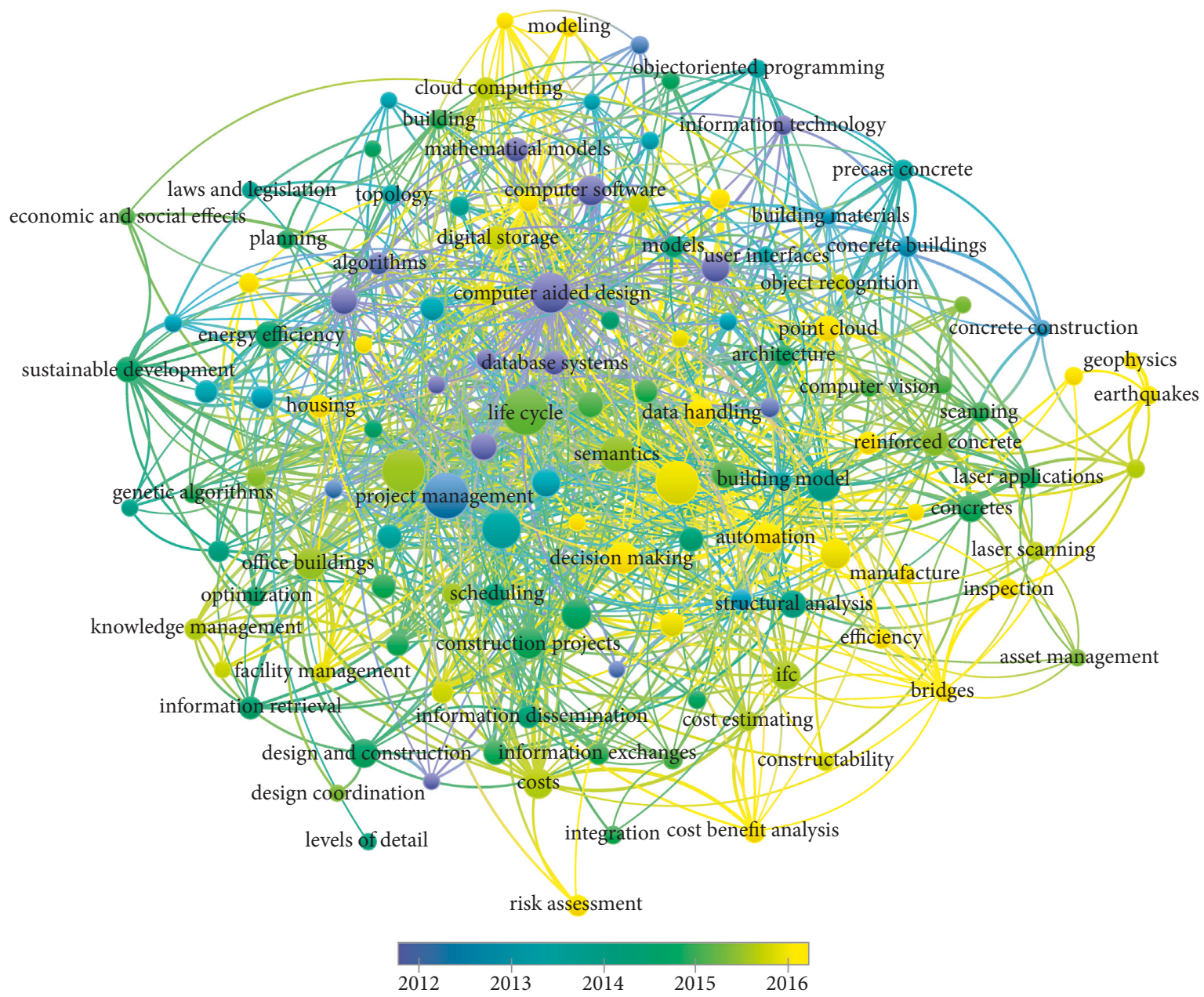

Figure 6: Cooccurrence map of keywords according to years.

(iii) 2016-2018: "simulation," "point cloud," "object detection," "automation," "classification," "model view definition (mvd)," "efficiency," "data handling," "inspection," "robotics," etc.

This analysis reveals the evolution of the BIM domain in the area of structural engineering has started with fundamental concepts like parametric design, computer simulations, and analysis of data structures, followed by a focus on the information management, interoperability, and collaboration in construction projects; the trend has shifted towards recent ideas of automation and big data analyses, decisionmaking, and development of knowledge management systems [75]. The interesting finding here is revealing the delayed attention paid to technical features and specific application of structural engineering within the BIM literature. That is, specialized applications of structural engineering are illustrated as isolated and small nodes in yellow color at the border of the circle of the network. This applies to all areas such as concrete construction, damage detection, floors, and retrofitting (see Figure 6). As such, research on BIM has been largely concerned with generic issues of integrating BIM into structural engineering practice and addressing common barriers that hinder BIM implementation on projects. The
TABLE 5: Keyword analysis (Scopus, December 2018).

\begin{tabular}{lccc}
\hline Keyword & Links & Occurrences & $\begin{array}{c}\text { Average } \\
\text { citations }\end{array}$ \\
\hline 2010-2012 & & & \\
project management & 91 & 38 & 11.37 \\
three dimensional & 138 & 33 & 33.59 \\
computer aided design & 95 & 28 & 22.96 \\
software design & 111 & 26 & 14.37 \\
database systems & 74 & 16 & 21.92 \\
algorithms & 47 & 9 & 20.44 \\
productivity & 35 & 7 & 26.86 \\
virtual reality & 28 & 7 & 19.71 \\
standards & 37 & 6 & 9.00 \\
civil engineering & 28 & 6 & 5.17 \\
in-buildings & 33 & 5 & 76.00 \\
building materials & 30 & 5 & 16.40 \\
concrete construction & 28 & 5 & 25.60 \\
\hline 2013-2015 & & & \\
architectural design & 146 & 258 & 14.84 \\
information systems & 181 & 140 & 14.00 \\
structural design & 130 & 126 & 15.80 \\
information management & 274 & 87 & 15.36 \\
industry foundation classes (ifc) & 254 & 71 & 19.20 \\
construction & 122 & 44 & 18.94 \\
\hline & & &
\end{tabular}


TABLE 5: Continued.

\begin{tabular}{|c|c|c|c|}
\hline Keyword & Links & Occurrences & $\begin{array}{l}\text { Average } \\
\text { citations }\end{array}$ \\
\hline life cycle & 95 & 38 & 10.68 \\
\hline design & 96 & 33 & 13.12 \\
\hline interoperability & 76 & 27 & 30.93 \\
\hline decision making & 109 & 26 & 15.81 \\
\hline cost estimating & 99 & 23 & 7.77 \\
\hline energy efficiency & 91 & 22 & 5.68 \\
\hline semantics & 81 & 22 & 19.32 \\
\hline concrete buildings & 94 & 21 & 14.27 \\
\hline construction projects & 69 & 18 & 17.56 \\
\hline sustainable development & 75 & 17 & 14.84 \\
\hline structural optimization & 70 & 17 & 13.51 \\
\hline office buildings & 63 & 17 & 27.53 \\
\hline visualization & 52 & 16 & 15.31 \\
\hline laser applications & 75 & 14 & 27.71 \\
\hline reinforced concrete & 58 & 14 & 6.21 \\
\hline design and construction & 51 & 14 & 29.93 \\
\hline structural analysis & 55 & 13 & 8.62 \\
\hline facility management & 79 & 12 & 27.73 \\
\hline AEC & 58 & 11 & 50.55 \\
\hline digital storage & 57 & 10 & 13.10 \\
\hline building codes & 49 & 10 & 11.80 \\
\hline construction management & 48 & 10 & 14.70 \\
\hline product design & 48 & 10 & 4.60 \\
\hline data visualization & 44 & 10 & 11.20 \\
\hline application programs & 49 & 9 & 5.00 \\
\hline scheduling & 48 & 9 & 38.11 \\
\hline intelligent buildings & 46 & 9 & 19.56 \\
\hline model checking & 43 & 9 & 62.00 \\
\hline cloud computing & 38 & 9 & 20.78 \\
\hline information retrieval & 35 & 9 & 10.78 \\
\hline ontology & 48 & 8 & 16.50 \\
\hline quality control & 47 & 8 & 15.38 \\
\hline precast concrete & 41 & 8 & 28.50 \\
\hline knowledge management & 39 & 8 & 13.00 \\
\hline architecture & 37 & 8 & 22.50 \\
\hline artificial intelligence & 45 & 7 & 14.71 \\
\hline building components & 44 & 7 & 13.43 \\
\hline building & 34 & 7 & 17.71 \\
\hline scanning & 33 & 7 & 48.43 \\
\hline topology & 30 & 7 & 12.71 \\
\hline compliance control & 30 & 7 & 6.71 \\
\hline social networking & 29 & 7 & 17.43 \\
\hline collaboration & 27 & 7 & 28.71 \\
\hline cost engineering & 44 & 6 & 16.00 \\
\hline specifications & 42 & 6 & 9.67 \\
\hline genetic algorithms & 39 & 6 & 21.50 \\
\hline software testing & 37 & 6 & 13.67 \\
\hline planning & 36 & 6 & 50.17 \\
\hline object oriented programming & 35 & 6 & 11.50 \\
\hline historic preservation & 32 & 6 & 18.00 \\
\hline damage detection & 29 & 6 & 10.67 \\
\hline integration & 28 & 6 & 8.00 \\
\hline earthquakes & 26 & 6 & 4.67 \\
\hline walls (structural partitions) & 25 & 6 & 43.67 \\
\hline constructability & 21 & 6 & 12.17 \\
\hline software prototyping & 41 & 5 & 14.40 \\
\hline user interfaces & 36 & 5 & 17.00 \\
\hline geometry & 29 & 5 & 32.20 \\
\hline conceptual design & 28 & 5 & 12.20 \\
\hline economic and social effects & 27 & 5 & 16.00 \\
\hline
\end{tabular}

TABle 5: Continued.

\begin{tabular}{|c|c|c|c|}
\hline Keyword & Links & Occurrences & $\begin{array}{l}\text { Average } \\
\text { citations }\end{array}$ \\
\hline search engines & 27 & 5 & 5.40 \\
\hline laws and legislation & 26 & 5 & 4.60 \\
\hline levels of detail & 25 & 5 & 26.40 \\
\hline floors & 25 & 5 & 51.00 \\
\hline design coordination & 23 & 5 & 21.40 \\
\hline asset management & 13 & 5 & 8.80 \\
\hline \multicolumn{4}{|l|}{$2016-2018$} \\
\hline simulation & 62 & 18 & 40.19 \\
\hline automation & 77 & 16 & 27.88 \\
\hline data handling & 65 & 13 & 7.54 \\
\hline point cloud & 43 & 11 & 37.45 \\
\hline housing & 47 & 9 & 9.89 \\
\hline maintenance & 46 & 9 & 4.67 \\
\hline cost benefit analysis & 28 & 8 & 4.88 \\
\hline risk assessment & 25 & 8 & 4.88 \\
\hline efficiency & 38 & 7 & 8.43 \\
\hline model view definition (mvd) & 33 & 7 & 11.86 \\
\hline human resource management & 32 & 7 & 17.86 \\
\hline classification & 44 & 7 & 13.00 \\
\hline inspection & 32 & 7 & 7.43 \\
\hline bridges & 34 & 6 & 6.67 \\
\hline information modeling & 33 & 6 & 6.50 \\
\hline manufacture & 22 & 6 & 2.67 \\
\hline geophysics & 21 & 5 & 3.20 \\
\hline big data & 26 & 5 & 5.80 \\
\hline robotics & 16 & 5 & 7.20 \\
\hline object detection & 61 & 10 & 32.70 \\
\hline
\end{tabular}

specialized and technical capabilities of BIM in various areas of structural engineering are hardly studied. The existing ones also remain isolated efforts disjointed from the main body of the BIM literature. This shows that the body of knowledge on the capabilities of BIM for integration with structural engineering practices is in its infancy. This can be explained in view of the fact that structural engineers still remain unsure of the risks and/or benefits of using BIM in performing their day-to-day activities and hence are uncertain of the potential to redesign their practices to align with the BIM methodology [84]. Moreover, the findings demonstrate fragmented and loosely coupled efforts in the absence of a coherent strategy or vision for integration of BIM into the structural engineering domain, and as a result, further research on these areas is much needed $[9,12,78]$.

5.4. Citation Network. Analysis of citation networks determines cocitation of journals and documents, demonstrating an analysis of the number of times papers cite each other [9]. A journal network was generated using the dataset; 116 journals were detected by VOSviewer. After applying VOSviewer algorithms and limiting the minimum number of citations of a source to 50 , the results pulled out 13 journals to form the main citation network (see Figure 7).

As it can be seen in Table 6, the most cited five journals are Automation in Construction (2374 citations, 82 articles), 


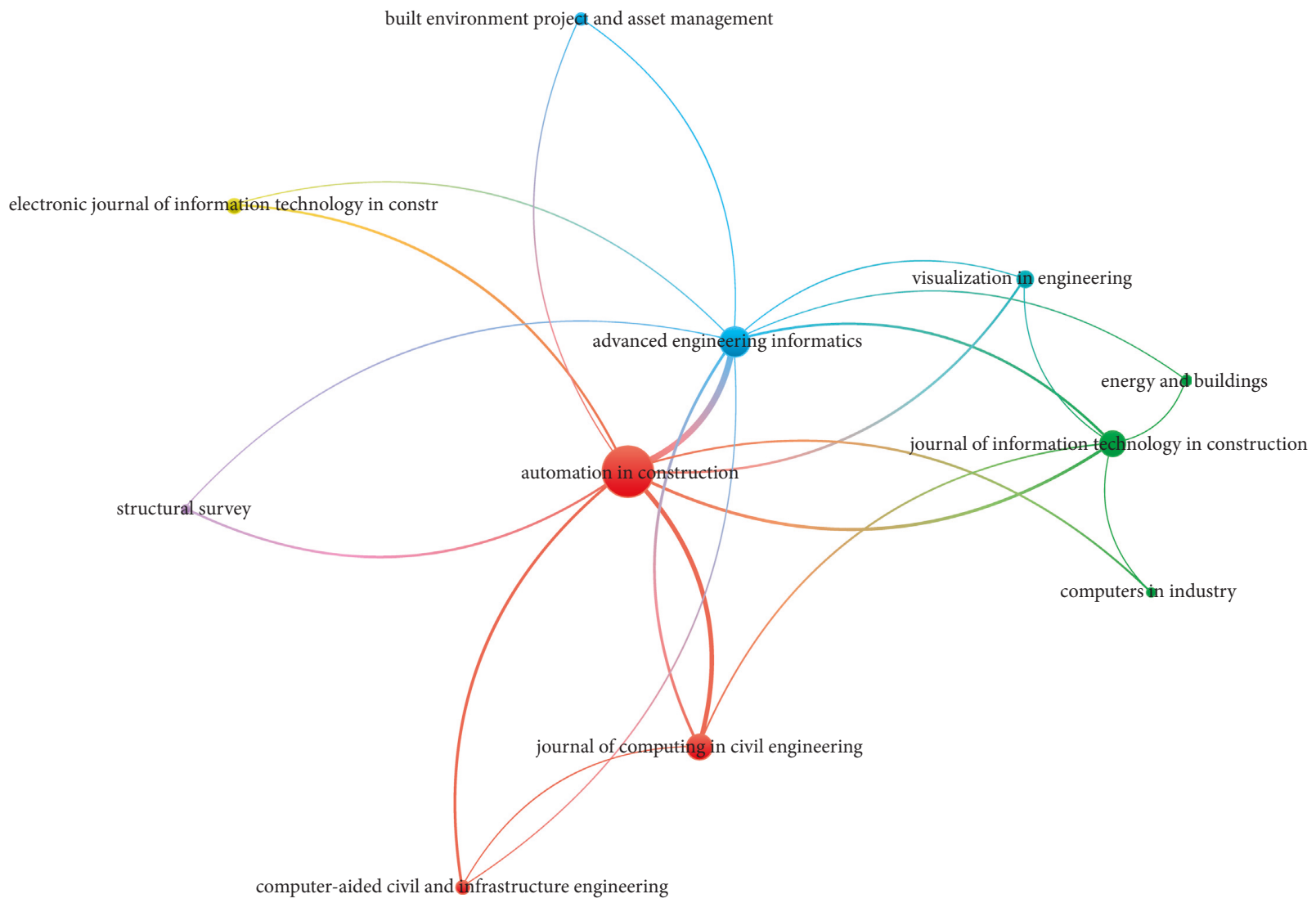

FIGURE 7: Citation network of journals.

Advanced Engineering Informatics (697 citations, 29 articles), Journal of Information Technology in Construction (337 citations, 28 articles), Journal of Computing in Civil Engineering (295 citations, 21 articles), and Visualization in Engineering (95 citations, 9 articles).

The citation network of articles is presented in Figure 8. After applying VOSviewer algorithms and limiting the minimum number of citations of an article to 15 , the results are shown in the form of a network with 85 articles as its nodes. Of these, only 55 articles have cited each other.

Eliminating self-citation in Scopus, an overall view emerges that slightly differs from that of Figure 8 (see Table 7). The most cited four articles are as follows: Zhang et al. [85] (198 subtotal and 225 total citations), Xiong et al. [86] (195 subtotal and 220 total citations), Singh et al. [87] (122 subtotal and 186 total citations), and Lee et al. [88] (77 subtotal and 167 total citations).

\section{Gaps and Future Areas for Research}

The analysis of results reveals that research on the topic of BIM in structural engineering has been an area experiencing significant growth, confirming the importance of applying BIM in structural engineering $[12,84]$. This growth, however, is merely a reflection of the growth of the overall number of articles on BIM triggered by the 2011 mandate of the Government Construction Strategy of the United Kingdom [73]; while the noticeable increase in BIM research
TABLE 6: The most cited journals.

\begin{tabular}{lccc}
\hline Journal & $\begin{array}{c}\text { Number of } \\
\text { citations* }\end{array}$ & $\begin{array}{c}\text { Number } \\
\text { of articles }\end{array}$ & $\begin{array}{c}\% \text { of } \\
\text { articles }\end{array}$ \\
\hline $\begin{array}{l}\text { Automation in Construction } \\
\text { Advanced Engineering }\end{array}$ & $\mathbf{2 3 7 4}$ & $\mathbf{8 2}$ & $\mathbf{2 2 . 2 2}$ \\
$\begin{array}{l}\text { Informatics } \\
\text { Journal of Information }\end{array}$ & $\mathbf{6 9 7}$ & $\mathbf{2 9}$ & $\mathbf{7 . 8 6}$ \\
$\begin{array}{l}\text { Technology in Construction } \\
\text { Journal of Computing in Civil }\end{array}$ & $\mathbf{3 3 7}$ & $\mathbf{2 8}$ & $\mathbf{7 . 5 9}$ \\
$\begin{array}{l}\text { Engineering } \\
\text { Visualization in Engineering }\end{array}$ & $\mathbf{2 9 5}$ & $\mathbf{2 1}$ & $\mathbf{5 . 6 9}$ \\
$\begin{array}{l}\text { Construction Innovation } \\
\text { Computer-Aided Civil and }\end{array}$ & 48 & $\mathbf{9 5}$ & $\mathbf{2 . 4 4}$ \\
$\begin{array}{l}\text { Infrastructure Engineering } \\
\text { Built Environment Project and }\end{array}$ & 79 & 7 & 1.90 \\
Asset Management & 57 & 6 & 1.63 \\
\hline
\end{tabular}

*Journals cited more than 40 times are included.

appears in $2012[9,65]$, structural engineering and BIM, as a topic, has come to the fore only after 2014. Previous studies have identified similar delays in conducting research on various BIM areas, where evidence refers to the delay for infrastructure, people side, and managerial areas of BIM [18]. This study highlights an analogous delay in research on structural engineering, revealing it as an area with major potential for implementing BIM. With the above in mind, this study, as an original insight provided, reveals that the now-available scientific literature on applications of BIM in 


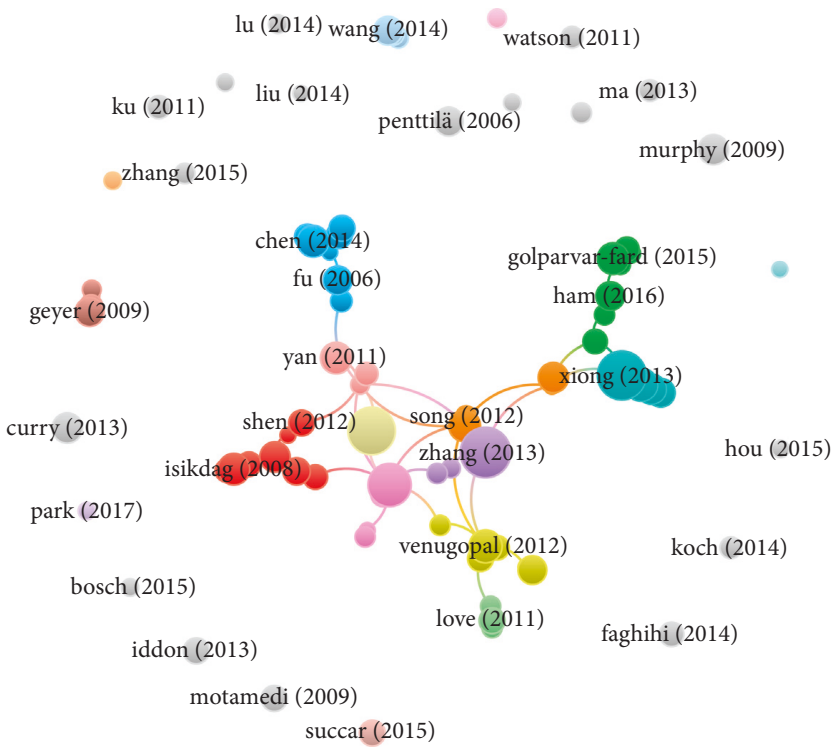

FIgURE 8: Citation network of articles.

TABLE 7: The most cited articles on BIM in the area of structural engineering excluding self-citation.

\begin{tabular}{|c|c|c|c|c|c|c|c|}
\hline Year & Reference & 2015 & 2016 & 2017 & 2018 & Subtotal (2015-2018) & Total $^{*}$ \\
\hline 2013 & Zhang et al. [85] & 29 & 47 & 59 & 60 & 198 & 225 \\
\hline 2013 & Xiong et al. [86] & 38 & 40 & 52 & 60 & 195 & 220 \\
\hline 2011 & Singh et al. [87] & 14 & 24 & 43 & 37 & 122 & 186 \\
\hline 2006 & Lee et al. [88] & 20 & 16 & 19 & 20 & 77 & 167 \\
\hline 2015 & Pătrăucean et al. [89] & 4 & 16 & 23 & 39 & 84 & 84 \\
\hline 2008 & Isikdag et al. [90] & 6 & 11 & 15 & 12 & 44 & 82 \\
\hline 2011 & Yan et al. [91] & 13 & 10 & 15 & 18 & 56 & 77 \\
\hline 2014 & Chen and Luo [92] & 8 & 15 & 23 & 29 & 75 & 75 \\
\hline 2009 & Jeong et al. [93] & 9 & 5 & 13 & 8 & 35 & 75 \\
\hline 2012 & Steel et al. [94] & 16 & 10 & 18 & 10 & 57 & 74 \\
\hline 2012 & Venugopal et al. [95] & 11 & 19 & 13 & 8 & 54 & 72 \\
\hline 2009 & Murphy et al. [96] & 4 & 10 & 18 & 23 & 56 & 68 \\
\hline 2008 & Arayici [97] & 9 & 11 & 13 & 13 & 47 & 68 \\
\hline \multirow[t]{2}{*}{2015} & Golparvar-Fard et al. [98] & 8 & 17 & 13 & 18 & 56 & 66 \\
\hline & Total count & 428 & 685 & 1057 & 1310 & 3594 & 4439 \\
\hline
\end{tabular}

${ }^{*}$ All years covered by Scopus.

structural engineering has been mainly concerned with generic issues of BIM like information management. As a result, BIM has much unexplored capacity for solving complex technical issues in specialized areas of structural engineering, another evidence for the infancy of BIM applications in the civil engineering field [9] and, in particular, structural engineering applications.

Another novelty of this study lies in its approach to bring together various applications of BIM in structural engineering from isolated studies in the literature, in the chronological order. The outcome is a point of reference that showcases all these applications, as a readily available reference frame for researchers, as well as practitioners. Research studies refer to much unexploited potential for using BIM in structural engineering, in integration with a bulk of available technologies for information management like classification tools based on [9] ontology rules, cloud computing, laser scanning, visualization techniques, simulation software, etc. Interested readers are referred to Sacks et al. [38] for details.

As another contribution of this study (illustrated in Figure 9), the findings demonstrate the evolution of BIM developments in areas associated with structural engineering, starting from the development of standards for computer-aided design, database systems, algorithms, software tools, and approaches to rise productivity. These developments are followed by shifting the focus towards information management, interoperability, and decisionmaking, eventually moving to the automation of processes, big data analytics, and simulation practices [19]. As the outcome, gaps and important areas for future research are identified, a description of which is as follows.

Automated modeling is deemed an essential element of various key applications like progress monitoring, status 


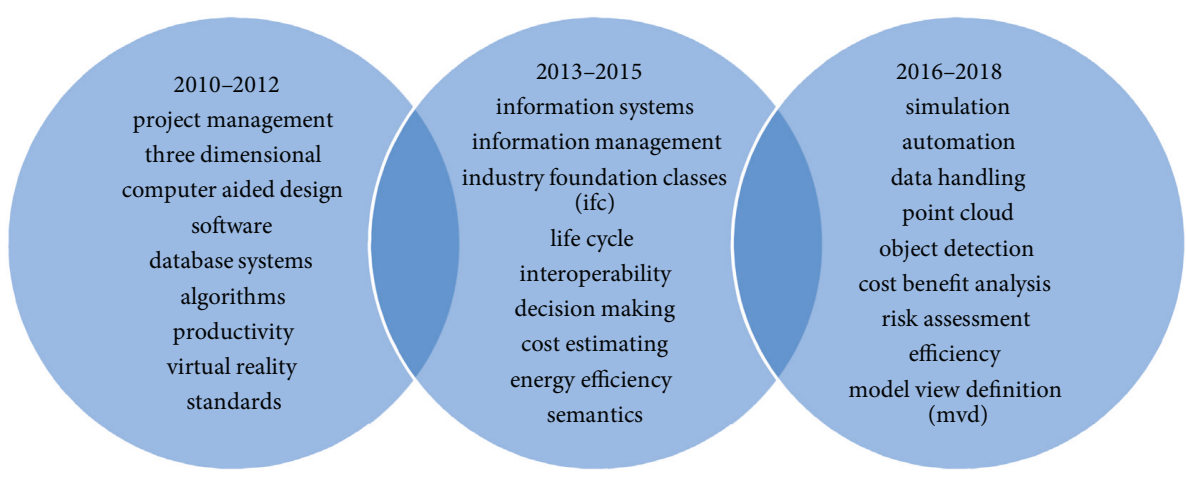

FIgURE 9: Evolvement directions of BIM in structural engineering.

assessment, and quality control. Therefore, an exponential growth of research efforts on automated construction progress monitoring is detected, in recent years.

The area, however, is still in its infancy [99]; that is, automated detection of structural elements within BIM models still is seen as a challenge, and hence, improving techniques and methods for accurate automated object identification-structural elements-within models is a ripe area for future studies [100].

With the sudden increase of interest in off-site construction-prefabrication-in many countries [101], increasing the prefabrication rate of precast concrete structures, automation of the assembly sequence and planning, and optimization must be topics important on the agenda within the domain of structural engineering [102]. With BIM in mind, future studies can target the unique characteristics of cast-in-place concrete in developing future versions of IFC, overlapping of structural elements, use of reinforcement bars, and the need for precision in loads and material considerations [103]. Automated creation of centralized accurate semantically rich as-built building information models of structural elements also remains a fertile area for future research, given various challenges that affect successful implementation of BIM for such purposes [104-107].

Dynamic structural health monitoring is another research area of paramount importance, to be considered for future investigation of BIM in the structural engineering domain. There is increasing demand for integration of BIM with data generated through sensors for live monitoring the health of structural elements [108]. Several ideas about automatic generation of BIM models of structural monitoring systems that include time-series sensor data that support dynamic visualization in an interactive 3D environment exist $[109,110]$, and the area remains in need of empirical studies to validate the proposed designs. These are hence future areas for research to promote the use of BIM in structural engineering.

\section{Conclusions}

This study is the first attempt in its kind in exploring the state of published research studies that link BIM with structural engineering. The area has attracted much interest, and some research efforts in the form of literature reviews are available in related fields like infrastructure engineering and civil engineering applications. Nevertheless, this study stands out. This is because this study offers a picture of the landscape of the body of BIM knowledge in relation to structural engineering, as an area that remains unexplored and unassessed. This study contributes to the field by diagnosing the problems of the literature from a holistic vantage point. It provides original insight into the issues revolving around technical aspects of structural engineering being overshadowed by challenges of BIM process implementation. This study also provides a point of reference to demonstrate what areas of BIM for structural engineering have been explored and what remain to be investigated, acting as an agenda for future research on the topic. In methodological terms, this study draws upon a quantitative analysis of citation networks, which involves minimal subjective judgment, making the findings reliable and reproducible. The findings presented contribute to the field by spotting the gaps to be addressed, trends to be redefined, and main areas of focus for future research. That is, the findings reveal that research on structural engineering applications of BIM is still in its infancy with many gaps; much remains yet to be done in making it an established domain of inquiry.

The clear message is that BIM-related issues like challenges of BIM implementation on projects have overshadowed the potential of BIM for structural engineering, and as such, existing studies have overlooked the technical issues of structural engineering to be resolved through the use of BIM. Moreover, the extant literature on the topic presents fragmented, isolated research efforts. And the isolation applies to the research subjects, active investigators, and their institutions, alike. These trends need reassessing and redefining, as highlighted by the findings of this study.

With the above in mind, future work-in the area of structural engineering and BIM-must target bringing in issues of structural engineering to be addressed and solved through applying BIM capabilities. Future research is needed through forming research collaborative networks that have enhancing dialogue, debate, and intracountry and intraorganization crossfermentation of initiatives and ideas, as their priorities. These findings raise awareness and enhance understanding of the necessity of addressing the identified gaps and neglected areas within the BIM literature. This contributes to directing deeper, 
more carefully selected, research into the field and assists policy-makers and industry partners of research projects in their plans for supporting and funding.

Despite the contributions associated with this study, all research studies have limitations, and this study is no exception. First, the analysis only covered the literature in English, using a certain set of keywords for searching. Second, the analysis was based on the dataset retrieved from Scopus; hence, it is affected by the limitations of Scopus in terms of coverage. Therefore, the findings may not fully reflect the entire available corpus of the BIM literature. Furthermore, this study, because of space limitations, was focused on providing a broad picture of the available literature on BIM for structural engineering through a bibliometric analysis of citation networks and less concerned with an in-depth content analysis of available studies. Nevertheless, before the bibliometric analysis of citation networks, authors made an in-depth qualitative analysis of the retrieved papers. A complementary study to analyze the content of available studies remains a ripe area for research on the topic.

\section{Data Availability}

The data generated in this research are available from the corresponding author on request.

\section{Conflicts of Interest}

The authors declare no conflicts of interest.

\section{References}

[1] S. Azhar, "Building information modeling (BIM): trends. benefits. risks. and challenges for the aec industry," Leadership and Management in Engineering, vol. 11, no. 3, pp. 241-252, 2011.

[2] G. Wang and J. Song, "The relation of perceived benefits and organizational supports to user satisfaction with building information model (BIM)," Computers in Human Behavior, vol. 68, pp. 493-500, 2017.

[3] M. Hu, "BIM-enabled pedagogy approach: using BIM as an instructional tool in technology courses," Journal of Professional Issues in Engineering Education and Practice, vol. 145, no. 1, article 05018017, 2018.

[4] B. Dasović, M. Galić, and U. Klanšek, "Active BIM approach to optimize work facilities and tower crane locations on construction sites with repetitive operations," Buildings, vol. 9, no. 1, p. 21, 2019.

[5] P. Gholizadeh, B. Esmaeili, and P. Goodrum, "Diffusion of building information modeling functions in the construction industry," Journal of Management in Engineering, vol. 34, no. 2, article 04017060, 2018.

[6] M. Galić, V. Venkrbec, F. Chmelik, I. Feine, Z. Pučko, and U. Klanšek, "Survey of accomplishments in BIM implementation in Croatia, The Czech Republic, Germany and Slovenia," E-GFOS, vol. 8, no. 15, pp. 23-35, 2017.

[7] C. Boton and D. Forgues, "Practices and processes in BIM projects: an exploratory case study," Advances in Civil Engineering, vol. 2018, Article ID 7259659, 12 pages, 2018.

[8] Y. Liu, S. van Nederveen, C. Wu, and M. Hertogh, "Sustainable infrastructure design framework through integration of rating systems and building information modeling," Advances in Civil Engineering, vol. 2018, Article ID 8183536, 13 pages, 2018.

[9] M. R. Hosseini, M. Maghrebi, A. Akbarnezhad, I. Martek, and M. Arashpour, "Analysis of citation networks in building information modeling research," Journal of Construction Engineering and Management, vol. 144, article 04018064, 2018.

[10] A. Bradley, H. Li, R. Lark, and S. Dunn, "BIM for infrastructure: an overall review and constructor perspective," Automation in Construction, vol. 71, pp. 139-152, 2016.

[11] I. Kaner, R. Sacks, W. Kassian, and T. Quitt, "Case studies of BIM adoption for precast concrete design by mid-sized structural engineering firms," Journal of Information Technology in Construction (ITcon), vol. 13, pp. 303-323, 2008.

[12] T. Bartley, "BIM for civil and structural engineers,"2017, BSI, London, UK, http://biblus.accasoftware.com/en/wpcontent/uploads/sites/2/2017/10/BIM-for-Civil-and-StructuralEngineers.pdf.

[13] H. Abdirad, "Metric-based BIM implementation assessment: a review of research and practice," Architectural Engineering and Design Management, vol. 13, no. 1, pp. 52-78, 2017.

[14] X. Li, P. Wu, G. Q. Shen, X. Wang, and Y. Teng, "Mapping the knowledge domains of building information modeling (BIM): a bibliometric approach," Automation in Construction, vol. 84, pp. 195-206, 2017.

[15] X. Zhao, "A scientometric review of global BIM research: analysis and visualization," Automation in Construction, vol. 80, pp. 37-47, 2017.

[16] F. Rodrigues, J. Teixeira, R. Matos, and H. Rodrigues, "Development of a web application for historical building management through BIM technology," Advances in Civil Engineering, vol. 2019, Article ID 9872736, 15 pages, 2019.

[17] Z. Aziz, Z. Riaz, and M. Arslan, "Leveraging BIM and big data to deliver well maintained highways," Facilities, vol. 35, no. 13/14, pp. 818-832, 2017.

[18] Q. He, G. Wang, L. Luo, Q. Shi, J. Xie, and X. Meng, "Mapping the managerial areas of building information modeling (BIM) using scientometric analysis," International Journal of Project Management, vol. 35, no. 4, pp. 670-685, 2017.

[19] M. Oraee, M. R. Hosseini, E. Papadonikolaki, R. Palliyaguru, and M. Arashpour, "Collaboration in BIM-based construction networks: a bibliometric-qualitative literature review," International Journal of Project Management, vol. 35, no. 7, pp. 1288-1301, 2017.

[20] M. Oraee, M. R. Hosseini, D. J. Edwards, H. Li, E. Papadonikolaki, and D. Cao, "Collaboration barriers in BIM-based construction networks: a conceptual model," International Journal of Project Management, vol. 37, no. 6, pp. 839-854, 2019.

[21] H. Guo, Y. Yu, and M. Skitmore, "Visualization technologybased construction safety management: a review," Automation in Construction, vol. 73, pp. 135-144, 2017.

[22] M. D. Martínez-Aires, M. López-Alonso, and M. MartínezRojas, "Building information modeling and safety management: a systematic review," Safety Science, vol. 101, pp. 11-18, 2018.

[23] R. Jin, P. X. W. Zou, P. Piroozfar et al., "A science mapping approach based review of construction safety research," Safety Science, vol. 113, pp. 285-297, 2019.

[24] H. Abdirad and C. S. Dossick, "BIM curriculum design in architecture. engineering. and construction education: a 
systematic review," Journal of Information Technology in Construction, vol. 21, pp. 250-271, 2016.

[25] Z. Xu, T. Huang, B. Li, H. Li, and Q. Li, "Developing an IFCbased database for construction quality evaluation," Advances in Civil Engineering, vol. 2018, Article ID 3946051, 22 pages, 2018.

[26] J. C. P. Cheng, Q. Lu, and Y. Deng, "Analytical review and evaluation of civil information modeling," Automation in Construction, vol. 67, pp. 31-47, 2016.

[27] C. A. Hunt, The Benefits of Using Building Information Modeling in Structural Engineering, Utah State University, Logan, Utah, 2013.

[28] M. Hammersley, "On "systematic" reviews of research literatures: a "narrative" response to evans \& benefield," British Educational Research Journal, vol. 27, no. 5, pp. 543-554, 2001.

[29] R. Jin, J. Zuo, and J. Hong, "Scientometric review of articles published in ASCE's journal of construction engineering and management from 2000 to 2018," Journal of Construction Engineering and Management, vol. 145, article 06019001, 2019.

[30] M. P. Markoulli, C. I. S. G. Lee, E. Byington, and W. A. Felps, "Mapping human resource management: reviewing the field and charting future directions," Human Resource Management Review, vol. 27, no. 3, pp. 367-396, 2017.

[31] S. Chin, S. Yoon, C. Choi, and C. Cho, "RFID + 4D CAD for progress management of structural steel works in high-rise buildings," Journal of Computing in Civil Engineering, vol. 22, no. 2, pp. 74-89, 2008.

[32] M. Sun, W. J. Staszewski, and R. N. Swamy, "Smart sensing technologies for structural health monitoring of civil engineering structures," Advances in Civil Engineering, vol. 2010, Article ID 724962, 13 pages, 2010.

[33] A. Charleson, Structure as Architecture, Routledge, Abingdon, UK, 2006.

[34] Z. Pezeshki and S. A. S. Ivari, "Applications of BIM: a brief review and future outline," Archives of Computational Methods in Engineering, vol. 25, no. 2, pp. 273-312, 2018.

[35] O. P. Larsen and A. Tyas, Conceptual Structural Design: Bridging the Gap between Architects and Engineers, Thomas Telford, London, UK, 2003.

[36] C. Eastman, P. Teicholz, R. Sacks, and K. Liston, BIM Handbook: A Guide to Building Information Modeling for Owners, Managers, Designers, Engineers and Contractors, John Wiley \& Sons, Hoboken, NJ, USA, 2011.

[37] M. Bilal, L. O. Oyedele, J. Qadir et al., "Big data in the construction industry: a review of present status. opportunities. and future trends," Advanced Engineering Informatics, vol. 30, no. 3, pp. 500-521, 2016.

[38] R. Sacks, C. Eastman, G. Lee, and P. Teicholz, "BIM for architects and engineers," in BIM Handbook, R. Sacks, C. Eastman, G. Lee, and P. Teicholz, Eds., John Wiley \& Sons, Hoboken, NJ, USA, 2018.

[39] E. Papadonikolaki, R. Vrijhoef, and H. Wamelink, "The interdependences of BIM and supply chain partnering: empirical explorations," Architectural Engineering and Design Management, vol. 12, no. 6, pp. 476-494, 2016.

[40] A. Strafaci, "What does BIM mean for civil engineers? 2008, http://images.autodesk.com/adsk/files/what_does_BIM_mean_ for_civil_engineers_ce_news_1008.pdf.

[41] S. Abrishami, J. Goulding, F. Pour Rahimian, and A. Ganah, "Virtual generative BIM workspace for maximising AEC conceptual design innovation," Construction Innovation, vol. 15, no. 1, pp. 24-41, 2015.
[42] A. Okakpu, A. GhaffarianHoseini, J. Tookey, J. Haar, A. Ghaffarianhoseini, and A. Rehman, "A proposed framework to investigate effective BIM adoption for refurbishment of building projects," Architectural Science Review, vol. 61, no. 6, pp. 467-479, 2018.

[43] M. Marzouk and M. Hisham, "Implementing earned value management using bridge information modeling," KSCE Journal of Civil Engineering, vol. 18, no. 5, pp. 1302-1313, 2014.

[44] V. Kasireddy, S. Ergan, B. Akinci, and N. S. Gulgec, "Visualization requirements of engineers for risk assessment of embankment dams," Visualization in Engineering, vol. 3, no. 1, p. 1, 2015.

[45] Y. Zhang, D. Zhong, B. Wu, T. Guan, P. Yue, and H. Wu, "3D parametric modeling of complex geological structures for geotechnical engineering of dam foundation based on Tsplines," Computer-Aided Civil and Infrastructure Engineering, vol. 33, no. 7, pp. 545-570, 2018.

[46] P. Kosky, R. Balmer, W. Keat, and G. Wise, "Chapter 7-civil engineering," in Exploring Engineering, R. Balmer, W. Keat, and G. Wise, Eds., pp. 127-160, Academic Press, Boston, MA, USA, 3rd edition, 2013.

[47] S. Alsafouri and S. K. Ayer, "Review of ict implementations for facilitating information flow between virtual models and construction project sites," Automation in Construction, vol. 86, pp. 176-189, 2018.

[48] S. Bruno, M. De Fino, and F. Fatiguso, "Historic building information modelling: performance assessment for diagnosis-aided information modelling and management," Automation in Construction, vol. 86, pp. 256-276, 2018.

[49] R. Volk, J. Stengel, and F. Schultmann, "Building Information Modeling (BIM) for existing buildings-literature review and future needs," Automation in Construction, vol. 38, pp. 109-127, 2014.

[50] Y. Lu, Z. Wu, R. Chang, and Y. Li, "Building information modeling (BIM) for green buildings: a critical review and future directions," Automation in Construction, vol. 83, pp. 134-148, 2017.

[51] K. Davies, S. Wilkinson, and D. McMeel, "A review of specialist role definitions in BIM guides and standards," Journal of Information Technology in Construction (ITcon), vol. 22, pp. 185-203, 2017.

[52] R. Edirisinghe, K. A. London, P. Kalutara, and G. ArandaMena, "Building information modelling for facility management: are we there yet?," Engineering. Construction and Architectural Management, vol. 24, no. 6, pp. 1119-1154, 2017.

[53] J. Matthews, P. E. D. Love, J. Mewburn, C. Stobaus, and C. Ramanayaka, "Building information modelling in construction: insights from collaboration and change management perspectives," Production Planning \& Control, vol. 29, no. 3, pp. 202-216, 2018.

[54] M. Laakso and L. Nyman, "Exploring the relationship between research and BIM standardization: a systematic mapping of early studies on the IFC standard (1997-2007)," Buildings, vol. 6, no. 1, p. 7, 2016.

[55] T. O. Olawumi, D. W. M. Chan, and J. K. W. Wong, "Evolution in the intellectual structure of BIM research: a bibliometric analysis," Journal of Civil Engineering and Management, vol. 23, no. 8, pp. 1060-1081, 2017.

[56] E. A. Pärn and D. Edwards, "Vision and advocacy of optoelectronic technology developments in the AECO sector," Built Environment Project and Asset Management, vol. 7, no. 3, pp. 330-348, 2017. 
[57] E. A. Pärn, D. J. Edwards, and M. C. P. Sing, "The building information modelling trajectory in facilities management: a review," Automation in Construction, vol. 75, pp. 45-55, 2017.

[58] M. Hilal, T. Maqsood, and A. Abdekhodaee, "A scientometric analysis of BIM studies in facilities management," International Journal of Building Pathology and Adaptation, vol. 37, no. 2, pp. 122-139, 2018.

[59] B. Soust-Verdaguer, C. Llatas, and A. García-Martínez, "Critical review of BIM-based LCA method to buildings," Energy and Buildings, vol. 136, pp. 110-120, 2017.

[60] Y. Song, X. Wang, Y. Tan et al., "Trends and opportunities of BIM-GIS integration in the architecture. engineering and construction industry: a review from a spatio-temporal statistical perspective," ISPRS International Journal of GeoInformation, vol. 6, no. 12, p. 397, 2017.

[61] A. Darko, A. P. C. Chan, X. Huo, and D.-G. Owusu-Manu, "A scientometric analysis and visualization of global green building research," Building and Environment, vol. 149, pp. 501-511, 2019.

[62] H. Y. Chong, R. Lopez, J. Wang, X. Wang, and Z. Zhao, "Comparative analysis on the adoption and use of BIM in road infrastructure projects," Journal of Management in Engineering, vol. 32, article 05016021, 2016.

[63] A. Kylili and P. A. Fokaides, "Policy trends for the sustainability assessment of construction materials: a review," Sustainable Cities and Society, vol. 35, pp. 280-288, 2017.

[64] R. Lopez, H.-Y. Chong, X. Wang, and J. Graham, “Technical review: analysis and appraisal of four-dimensional building information modeling usability in construction and engineering projects," Journal of Construction Engineering and Management, vol. 142, article 06015005, 2015.

[65] R. Santos, A. A. Costa, and A. Grilo, "Bibliometric analysis and review of building information modelling literature published between 2005 and 2015," Automation in Construction, vol. 80, pp. 118-136, 2017.

[66] T. Ganbat, H.-Y. Chong, P.-C. Liao, and Y.-D. Wu, "A bibliometric review on risk management and building information modeling for international construction," $A d$ vances in Civil Engineering, vol. 2018, Article ID 8351679, 13 pages, 2018.

[67] R. Jin, Y. Zou, K. Gidado, P. Ashton, and N. Painting, "Scientometric analysis of BIM-based research in construction engineering and management," Engineering, Construction and Architectural Management, 2019.

[68] C. Merschbrock and B. E. Munkvold, "A research review on building information modeling in construction-an area ripe for IS research," Communications of the Association for Information Systems, vol. 31, 2012.

[69] H. Arksey and L. O'Malley, "Scoping studies: towards a methodological framework," International Journal of Social Research Methodology, vol. 8, no. 1, pp. 19-32, 2005.

[70] B. Kitchenham, O. Pearl Brereton, D. Budgen, M. Turner, J. Bailey, and S. Linkman, "Systematic literature reviews in software engineering-a systematic literature review," Information and Software Technology, vol. 51, no. 1, pp. 7-15, 2009.

[71] H. Zhang, B. Kitchenham, and D. Pfahl, "Reflections on 10 years of software process simulation modeling: a systematic review," in Proceedings of the International Conference on Software Process, pp. 345-356, Springer, Beijing, China, October 2008.

[72] L. Waltman and N. J. Van Eck, "A smart local moving algorithm for large-scale modularity-based community detection," European Physical Journal B, vol. 86, no. 11, p. $471,2013$.

[73] Cabinet Office, "Government construction strategy," 2011, https://assets.publishing.service.gov.uk/government/uploads/ system/uploads/attachme_nt_data/file/61152/GovernmentConstruction-Strategy_0.pdf.

[74] E. Papadonikolaki, "Loosely coupled systems of innovation: aligning BIM adoption with implementation in Dutch construction," Journal of Management in Engineering, vol. 34, article 05018009, 2018.

[75] T. O. Olawumi and D. W. M. Chan, "Building information modelling and project information management framework for construction projects," Journal of Civil Engineering and Management, vol. 25, no. 1, pp. 53-75, 2019.

[76] G. Mignone, M. R. Hosseini, N. Chileshe, and M. Arashpour, "Enhancing collaboration in BIM-based construction networks through organisational discontinuity theory: a case study of the new royal adelaide hospital," Architectural Engineering and Design Management, vol. 12, no. 5, pp. 333-352, 2016.

[77] W. Shou, J. Wang, X. Wang, and H. Y. Chong, "A comparative review of building information modelling implementation in building and infrastructure industries," Archives of Computational Methods in Engineering, vol. 22, no. 2, pp. 291-308, 2015.

[78] B. Fanning, C. M. Clevenger, M. E. Ozbek, and H. Mahmoud, "Implementing BIM on infrastructure: comparison of two bridge construction projects," Practice Periodical on Structural Design and Construction, vol. 20, no. 4, article 04014044, 2015.

[79] Y. Ding, "Scientific collaboration and endorsement: network analysis of coauthorship and citation networks," Journal of Informetrics, vol. 5, no. 1, pp. 187-203, 2011.

[80] N. J. Van Eck and L. Waltman, "Visualizing bibliometric networks," in Measuring Scholarly Impact, pp. 285-320, Springer, Berlin, Germany, 2014.

[81] M. E. J. Newman, "Coauthorship networks and patterns of scientific collaboration," Proceedings of the National Academy of Sciences, vol. 101, no. Supplement 1, pp. 5200-5205, 2004.

[82] R. Jin, P. X. Zou, B. Li, P. Piroozfar, and N. Painting, "Comparisons of students' perceptions on BIM practice among Australia. China and UK," Engineering, Construction and Architectural Management, 2019.

[83] H.-N. Su and P.-C. Lee, "Mapping knowledge structure by keyword co-occurrence: a first look at journal papers in technology foresight," Scientometrics, vol. 85, no. 1, pp. 6579, 2010.

[84] A. Whyte and J. Donaldson, "Digital model data distribution in civil engineering contracts," Built Environment Project and Asset Management, vol. 5, no. 3, pp. 248-260, 2015.

[85] S. Zhang, J. Teizer, J.-K. Lee, C. M. Eastman, and M. Venugopal, "Building information modeling (BIM) and safety: automatic safety checking of construction models and schedules," Automation in Construction, vol. 29, pp. 183-195, 2013.

[86] X. Xiong, A. Adan, B. Akinci, and D. Huber, "Automatic creation of semantically rich $3 \mathrm{D}$ building models from laser scanner data," Automation in Construction, vol. 31, pp. 325-337, 2013.

[87] V. Singh, N. Gu, and X. Wang, "A theoretical framework of a BIM-based multi-disciplinary collaboration platform," $\mathrm{Au}$ tomation in Construction, vol. 20, no. 2, pp. 134-144, 2011. 
[88] G. Lee, R. Sacks, and C. M. Eastman, "Specifying parametric building object behavior (BOB) for a building information modeling system," Automation in Construction, vol. 15, no. 6, pp. 758-776, 2006.

[89] V. Pătrăucean, I. Armeni, M. Nahangi, J. Yeung, I. Brilakis, and C. Haas, "State of research in automatic as-built modelling," Advanced Engineering Informatics, vol. 29, no. 2, pp. 162-171, 2015.

[90] U. Isikdag, J. Underwood, and G. Aouad, “An investigation into the applicability of building information models in geospatial environment in support of site selection and fire response management processes," Advanced Engineering Informatics, vol. 22, no. 4, pp. 504-519, 2008.

[91] W. Yan, C. Culp, and R. Graf, "Integrating BIM and gaming for real-time interactive architectural visualization," Automation in Construction, vol. 20, no. 4, pp. 446-458, 2011.

[92] L. Chen and H. Luo, "A BIM-based construction quality management model and its applications," Automation in Construction, vol. 46, pp. 64-73, 2014.

[93] Y.-S. Jeong, C. M. Eastman, R. Sacks, and I. Kaner, "Benchmark tests for BIM data exchanges of precast concrete," Automation in Construction, vol. 18, no. 4, pp. 469484, 2009.

[94] J. Steel, R. Drogemuller, and B. Toth, "Model interoperability in building information modelling," Software \& Systems Modeling, vol. 11, no. 1, pp. 99-109, 2012.

[95] M. Venugopal, C. M. Eastman, R. Sacks, and J. Teizer, "Semantics of model views for information exchanges using the industry foundation class schema," Advanced Engineering Informatics, vol. 26, no. 2, pp. 411-428, 2012.

[96] M. Murphy, E. McGovern, and S. Pavia, "Historic building information modelling (HBIM)," Structural Survey, vol. 27, no. 4, pp. 311-327, 2009.

[97] Y. Arayici, "Towards building information modelling for existing structures," Structural Survey, vol. 26, no. 3, pp. 210-222, 2008.

[98] M. Golparvar-Fard, F. Peña-Mora, and S. Savarese, "Automated progress monitoring using unordered daily construction photographs and IFC-based building information models," Journal of Computing in Civil Engineering, vol. 29, article 04014025, 2015.

[99] Z. Pučko, N. Šuman, and D. Rebolj, “Automated continuous construction progress monitoring using multiple workplace real time 3D scans," Advanced Engineering Informatics, vol. 38, pp. 27-40, 2018.

[100] M.-M. Sharif, M. Nahangi, C. Haas, and J. West, “Automated model-based finding of $3 \mathrm{D}$ objects in cluttered construction point cloud models," Computer-Aided Civil and Infrastructure Engineering, vol. 32, no. 11, pp. 893-908, 2017.

[101] M. Arashpour, A. Heidarpour, A. Akbar Nezhad, Z. Hosseinifard, N. Chileshe, and R. Hosseini, "Performancebased control of variability and tolerance in off-site manufacture and assembly: optimization of penalty on poor production quality," Construction Management and Economics, pp. 1-13, 2019.

[102] Y. Wang, Z. Yuan, and C. Sun, "Research on assembly sequence planning and optimization of precast concrete buildings," Journal of Civil Engineering and Management, vol. 24, no. 2, pp. 106-115, 2018.

[103] A. Garbers, F. Esmanioto, N. Huber, E. R. Loures, and O. Canciglieri, "Data interoperability assessment though IFC for BIM in structural design-a five-year gap analysis," Journal of Civil Engineering and Management, vol. 23, no. 7, pp. 943-954, 2017.
[104] F. Xue, W. Lu, and K. Chen, "Automatic generation of semantically rich as-built building information models using 2D images: a derivative-free optimization approach," Computer-Aided Civil and Infrastructure Engineering, vol. 33, no. 11, pp. 926-942, 2018.

[105] J. Jung, S. Hong, S. Yoon, J. Kim, and J. Heo, “Automated 3D wireframe modeling of indoor structures from point clouds using constrained least-squares adjustment for as- built BIM," Journal of Computing in Civil Engineering, vol. 30, article 04015074, 2016.

[106] Q. Wang, H. Sohn, and J. C. P. Cheng, “Automatic as-built BIM creation of precast concrete bridge deck panels using laser scan data," Journal of Computing in Civil Engineering, vol. 32, article 04018011, 2018.

[107] H.-Y. Lee and I. T. Yang, "Developing as-built BIM model process management system for general contractors: a case study," Journal of Civil Engineering and Management, vol. 22, no. 5, pp. 608-621, 2016.

[108] M. Theiler and K. Smarsly, "IFC monitor-an IFC schema extension for modeling structural health monitoring systems," Advanced Engineering Informatics, vol. 37, pp. 54-65, 2018.

[109] J. M. D. Delgado, L. J. Butler, I. Brilakis, M. Z. E. B. Elshafie, and C. R. Middleton, "Structural performance monitoring using a dynamic data-driven BIM environment," Journal of Computing in Civil Engineering, vol. 32, article 04018009, 2018.

[110] V. Petrovic, M. Yeager, and F. Kuester, "Terrestrial laser scanning for the comprehensive structural health assessment of the baptistery di san giovanni in florence. Italy: an integrative methodology for repeatable data acquisition. visualization and analysis auhess. michael," Structure and Infrastructure Engineering, vol. 14, pp. 247-263, 2018. 


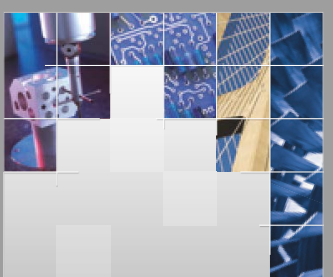

\section{Enfincering}
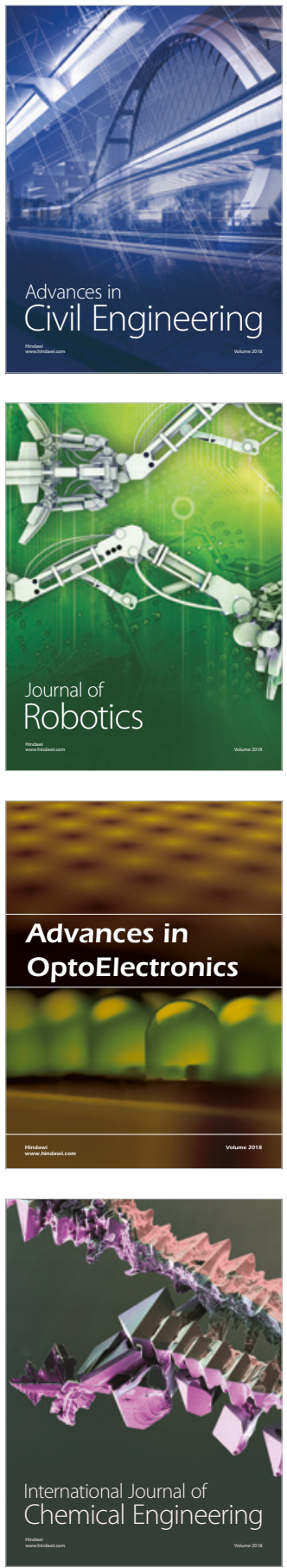

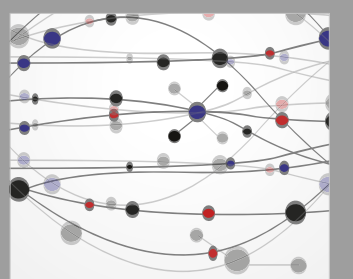

\section{Rotating \\ Machinery}

The Scientific World Journal

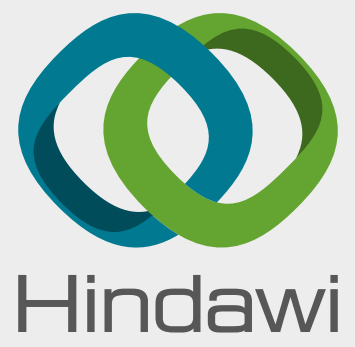

Submit your manuscripts at

www.hindawi.com
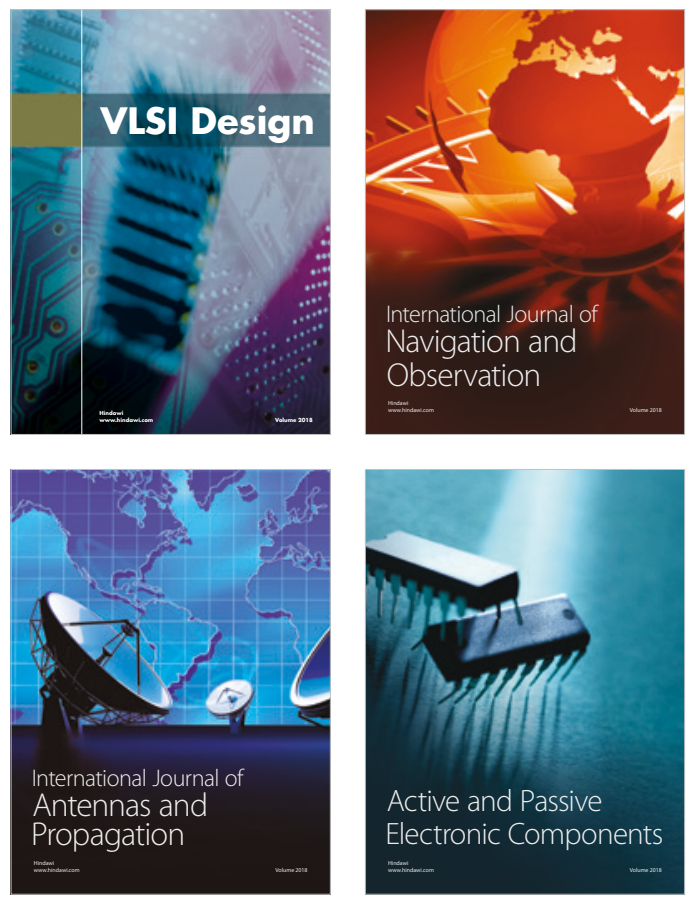
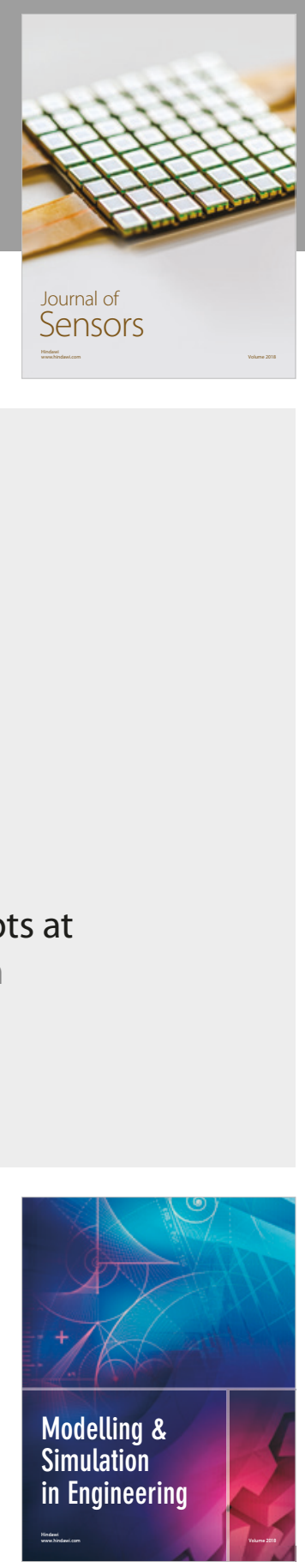

\section{Advances \\ Multimedia}
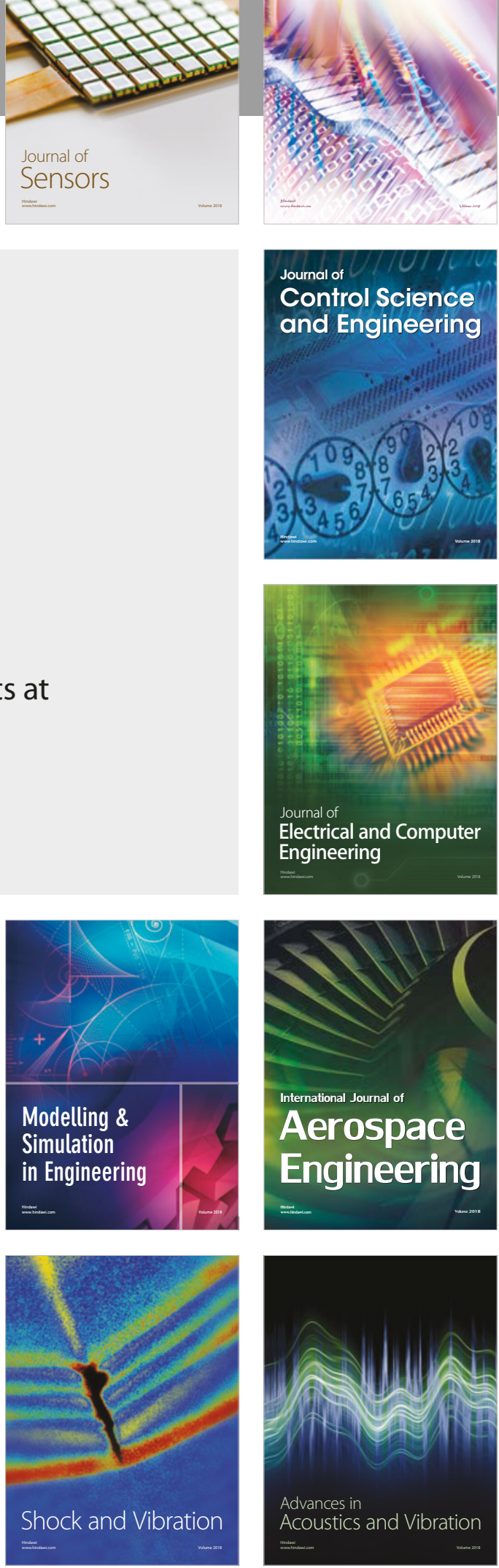